\title{
DEVELOPING SIMPLE PROCEDURES FOR SELECTING, SIZING, SCHEDULING OF MATERIALS AND COSTING OF SMALL BIO - GAS UNITS
}

\author{
James Kuria \\ Jomo Kenyatta University of Agriculture and Technology \\ P.O. Box 62000-00200 Nairobi, Tel: (067)52711, Kenya. \\ Email: kushkim05@yahoo.com \\ Maina Maringa \\ Jomo Kenyatta University of Agriculture and Technology \\ P.O. Box 62000-00200 Nairobi, Tel: (067)52711,Kenya \\ Email: maina wamaringa@yahoo.com
}

\begin{abstract}
The end users of biogas systems in most cases are farmers whose technical knowledge of the systems is limited. It is therefore important that material be availed to them which can assist them in making the decision whether to proceed with installation or not without having to hire professionals at a very early stage. The objectives of this study were to develop literature that could be used by laymen to assess the viability of installing biogas units and to size the biogas units with reference to a selected numbers of cows. A number of existing designs were analyzed and the floating drum design adopted based on a weighted-point approach that was developed in this study. Tables relating the number of cows to the size of a floating drum biogas unit and its cost of construction were developed.
\end{abstract}

Index Terms - Biogas, Floating Drum Digester, Methanogenic Bacteria, Slurry.

NOMENCLATURE

$H \quad$ Digester pit height

$V_{d} \quad$ Digester pit volume

$t \quad$ Thickness of concrete

$\mathrm{T}$ Temperature

$H \quad$ Gas holder height

$V_{g} \quad$ Gas holder volume

$v \quad$ Slurry feed rate

$h_{s} \quad$ Height of stone

$l \quad$ Length of stone

$R \quad$ Central radius of the digester

$R \quad$ Central radius of the digester
$N_{s} \quad$ Number of stones

$N_{c s} \quad$ Number of courses of stone

$\mathrm{N}_{\mathrm{T}} \quad$ Total Number if stones

$D \quad$ Digester pit diameter

$d_{i} \quad$ Diameter of influent chamber

$h_{i} \quad$ Height of influent chamber

$d_{o} \quad$ Diameter of effluent chamber

$h_{o} \quad$ Height of effluent chamber

$d_{x} \quad$ Diameter of partition

$h_{x} \quad$ Height of partition

$b \quad$ Width of building stones

\section{INTRODUCTION}

Like many other developing countries, Kenya faces a double energy crisis. Firstly, the country relies on imported petroleum for about $75 \%$ of its commercial energy needs and has no identified oil or gas reservoirs which could be used as a substitute for imported petroleum in the near future. The second energy crisis regards the increasing shortage of traditional 
energy sources in the form of wood and charcoal ${ }^{1}$. The national energy consumption matrix is as follows ${ }^{2}$ :

- $68 \%$ wood fuel and other biomass

- $22 \%$ petroleum

- $9 \%$ electricity

- $1 \%$ other

Use of wood and charcoal as a source of energy for the last fifteen years has resulted to a reduction of the country's forest cover by an average of 12,600 hectares of forest per year. This amounts to an average annual deforestation rate of $0.34 \%$. In total, between 1990 and 2005 , Kenya lost $5.0 \%$ of its forest cover, or around 186, 000 hectares. The forest cover in the country currently stands at $6.2 \%$ or 522,000 hectares, which is less than the $10 \%$ minimum forest cover that is stipulated by the government ${ }^{3}$. Clearly, therefore, wood and charcoal can no longer be treated as a desirable energy source.

Therefore, there is an urgent need to seek alternative renewable energy sources such as biogas. The energy requirements of the average Kenyan family, particularly in the rural families that comprise about $70 \%$ of the population, are in the form of cooking and water heating fuel ${ }^{4}$. This is easily met by small scale biogas plants which can in addition be used to provide domestic lighting. It is also possible to provide large scale heating and cooking solutions within the urban setting using larger biogas plants.

About $10 \%$ of the total grid power comes from diesel power plants while $90 \%$ comes from hydro-power. Domestic consumption accounts for about $68.8 \%$ of the total power consumed in the country ${ }^{5}$. Also important to note is the fact that the grid power supply today currently reaches only about $15 \%$ of the Kenyan population ${ }^{6}$, where power needs are mainly for water heating and cooking ${ }^{7}$. Currently over $80 \%$ of the country's hydro-power potential has been exploited. This implies that with growing demand for power, both industrial and domestic, the country's reliance on fossil fuel power or on imported power will grow.

There is a clear and urgent need to develop alternative sources of power which not only release existing power for use on industries but also allow easy, flexible and on the spot renewable power solutions to reach the majority of the nation's population. Biogas technology can therefore play a vital role in reducing the country's reliance on imported petroleum fuels as well as facilitating easy, cheap and flexible access to energy by the Kenyan population. Biogas technology is now widely used all over the world, with over 17 million family-sized low-technology biogas digester installed in China by the year 2005 and over 3500 farm based biogas digesters in Europe and North America, over 2000 high-rate biogas digesters installed in the world today ${ }^{8}$. In Europe alone a total of $50 \mathrm{TWh}$ of biogas was produced in the year 2004 and is expected to grow to $210 \mathrm{TWh}$ by the year $2020^{9}$.

Biogas is produced from the breakdown of complex molecules of proteins, carbohydrates and fats found in feedstock, by microscopic organisms referred to as acidogenic and methanogenic bacteria, in a process that produces energy and chemicals required by the bacteria to grow, with biogas as a by-product ${ }^{10}$. The bacteria used in a biogas digester are similar to those found in the gut of ruminant animals such as cattle. The bacteria are adapted to conditions similar to those found in a cow that is, temperatures near $37^{\circ} \mathrm{C}$, and the exclusion of air as well as light. The bacteria are therefore anaerobic. These conditions can be created by digging a hole into the ground and lining it with bricks and/or cement, to prevent the slurry mixture from leaking into the ground. A suitable cover is then provided to exclude light and air, and to collect the gas produced. In tropical and subtropical regions, the temperatures are usually conducive for biogas production during most of the year, while in cooler climates, some methods of insulating and heating the slurry must be provided ${ }^{11}$. 
The objectives of this work are:

- To provide literature that can easily be used by laymen to assess the viability of installing biogas units.

- To analyze and compare existing designs of biogas units and develop a method of identifying the most appropriate one.

- To completely size the selected biogas plant with reference to the number of cows.

- To develop a bill of quantities for the selected biogas unit.

\section{THE PRODUCTION OF BIOGAS}

Several bacteria are present in animal waste, compost and other feedstock each serving a specific function. The facultative bacteria in a digester break down complex feedstock molecules using oxygen in the feedstock and water through a process known as hydrolysis ${ }^{12}$. These bacteria function both in presence and absence of oxygen and require temperatures of about $37^{\circ} \mathrm{C}$. This is followed by the formation of volatile fatty acids, carbon dioxide and hydrogen by the acidogenic bacteria in a process referred to as acidogenesis. These bacteria function only in the absence of oxygen. If there is any air/oxygen present during this process, the digestion of the feedstock stops and the digester gives off a distinctive smell of the acids present $^{13}$. Finally the methanogenic bacteria break down the fatty acids in the feedstock into simpler molecules namely: carbon dioxide, water and methane in a process referred to as the methanogenesis ${ }^{14}$. These bacteria also function only in absence of oxygen. The composition of biogas depends heavily on the feedstock but mainly consists of $50-70 \%$ methane, $30-40 \%$ carbon dioxide, 5-10\% Hydrogen, 1-2\% nitrogen, $0.3 \%$ water vapor and trace amounts hydrogen sulfide ${ }^{15} 16 \quad 17$. Figure 1 below shows the stages in biogas production, discussed above.

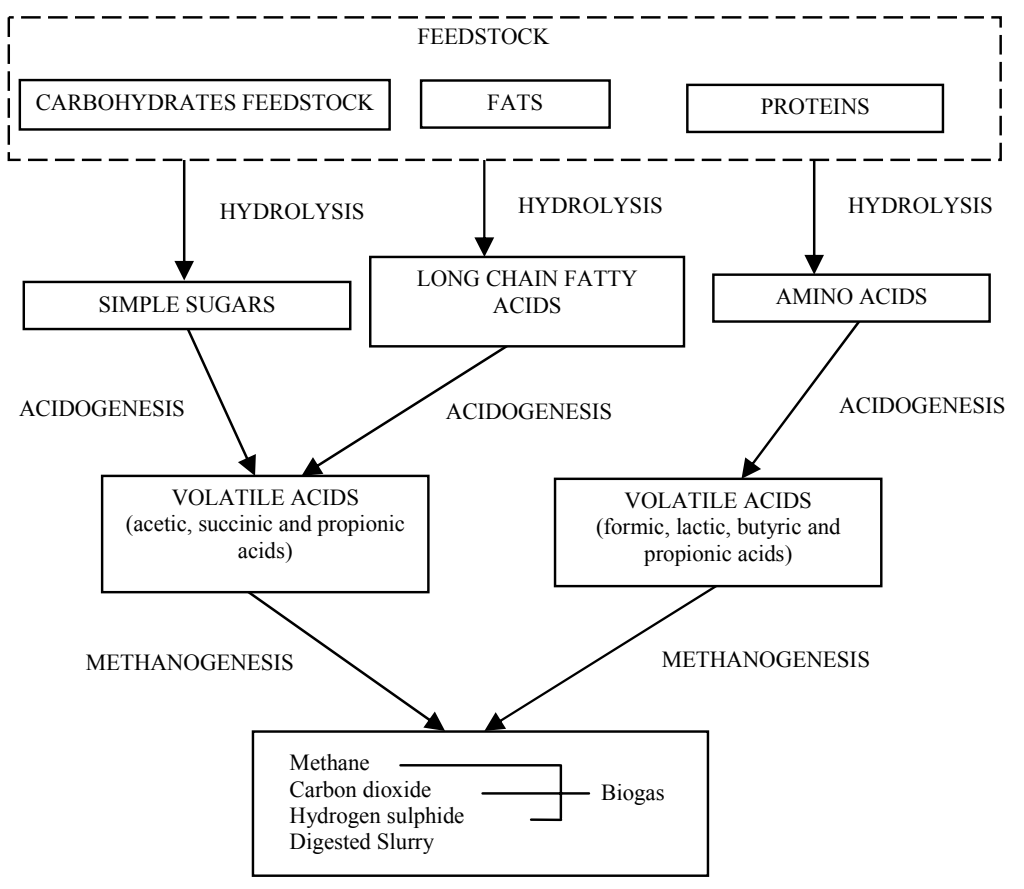

FIGURE 1

STAGES IN THE PRODUCTION OF BIOGAS ${ }^{18}$ 
The main controlling factors in the production of biogas are the loading rate, retention time and temperature of the biogas digester ${ }^{19}$. The loading rate will vary with digester feedstock and types of digesters but is normally given in terms of the weight of the total volatile solids (TVS) per day per unit volume of the digester or the weight of TVS added per day per weight of TVS already in the digester ${ }^{20}$. Volatile solids define the amount of organic matter in a material or the organic component that is burnt off when a material is heated to $538{ }^{0} \mathrm{C}^{21}{ }^{22}$. The higher the volatile solid content in a substrate, the higher the amount of biogas produced ${ }^{23}$. Over-loading leads to increased acidity of the digester and the attendant reduction in the production of methane, while under-loading gives rise to low gas production $^{24}$. The retention time is a measure of the amount of time a substrate remains in the digester before being discharged and is normally equal to the volume of the digester divided by the daily inputs of substrate ${ }^{25} 26$. It is important to optimize the retention time in order to ensure, proper digestion of the slurry and extraction of as much biogas as possible before discharge of the slurry. The cellulose, hemicellulose and lignin components in fibre are difficult to bio-degrade, which contributes to a reduction in the production and content of methane in biogas from the high fibre content cow manure substrate. It is necessary therefore to introduce phase separation processes that separate the fibre from the rest of the substrate so that the fibre may be digested for longer periods apart from the rest of the substrate. The efficiency of phase separation processes however are dependent on a number of factors including, the type of substrate, organic loading rate (OLR), hydraulic retention time (HRT) and the configuration of digester reactors used ${ }^{27}$.

Biogas is one of the three most widely used fuel gases together with natural gas and Liquid petroleum gas $(\mathrm{LPG})^{28}$. LPG is comprised of volatile fractions from petroleum refining principally; butane, propane, propylene and butylenes ${ }^{29}$. The characteristics of biogas lie between those of town gas and natural gas, the former which is obtained by cracking of cokes $^{30}$. Methane, the flammable component of biogas, produces about a half of the carbon dioxide produced by other fuels for the same fuel value when burnt and does not emit carbon monoxide thus making it safe for domestic use. It has a comparatively slow burning flame velocity of $430 \mathrm{mms}^{-1}$, which gives the fuel a high octane number thus making it good for use in internal combustion engines ${ }^{31}$. Biogas is mainly produced through the anaerobic digestion of animal and plant organic waste, primarily in simple and low technology systems. Biodigestion is not solely attractive for the methane gas produced but also as it provides a means of converting organic waste that would otherwise be an environmental hazard into readily usable compost, reduction of pathogens in the organic waste, odor control, mineralization of organic nitrogen and weed seed destruction 32334 .

The main by-products of bio-methane production, carbon dioxide and hydrogen sulfide, increase the storage and handling requirements of biogas, reduce the gas value of the biogas produced, in addition to which hydrogen sulfide is pungent. It is therefore advisable to remove these gases from the biogas before storage or use ${ }^{35}$. Efficient storage of methane, like natural gas, requires that it be compressed into an easily stored and transporter liquid. Methane unlike butane however, is not easily liquefied by pressure at normal temperatures and is only easily amendable to pressure-liquefaction at cryogenic temperatures ${ }^{36}$. Storage in Structure I (sI), Structure II (sII) or Structure H (sH) hydrates reduces the low temperature requirements for the liquefaction of methane and natural gas ${ }^{37}$. The formation pressure requirements in the storage of methane can be reduced by filling the large cages in sI and sII hydrates and stabilizing the largest cage in $\mathrm{sH}$ hydrates ${ }^{38}$. Experimental volume reductions of methane stored in sI, sII and sH hydrates of 56, 154 and 201, respectively, have been recorded, which compare well with the known Liquid Natural Gas (LNG) volume reduction of 600 at $-162{ }^{0} \mathrm{C}^{39}$. The main constituent of natural gas, like biogas, is methane, with $5-16 \%$ 
ethane and up to $8 \%$ hydrogen ${ }^{40}$. As the present study is concerned with simple ways of availing biogas technology to farmers in the country, it is expected that excess methane gas that cannot be used immediately would be stored in side collection tanks as is without being pressurized or without result to special storage treatment such as those described above.

\section{UNDESIRABLE GASES IN BIOGAS}

The need to remove Carbon Dioxide, Hydrogen Sulphide and water vapour from biogas is done for various reasons including, use requirements, need to increase the heat content and for purposes of standardizing the gas. Table I below shows some use requirements for various gaseous components of biogas ${ }^{41}{ }^{42}$ :

TABLE I

USE DEPENDENT NEED OF REMOVING VARIOUS GASEOUS COMPONENTS IN BIOGAS ${ }^{43} 44$

\begin{tabular}{lccc}
\hline \multicolumn{1}{c}{ Use } & $\mathbf{H}_{2} \mathbf{S}$ & $\mathbf{C O}_{2}$ & $\mathbf{H}_{2} \mathbf{O}$ \\
Gas Heater (Boiler) & $<1000 \mathrm{ppm}$ & no & no \\
\hline Kitchen Stove & yes & no & no \\
Stationary Gas Engine & $<1000 \mathrm{ppm}$ & no & No condensation \\
Vehicle Fuel & yes & Recommended & yes \\
Natural Gas Grid & yes & no & yes \\
\hline
\end{tabular}

Water vapor is present in biogas in proportions varying from $5 \%$ to saturation ${ }^{45}$ and combines with hydrogen sulfide and carbon dioxide to form the very reactive sulfuric acid and the mild carbonic acid $^{46}$. Hydrogen sulfide concentrations of less than $1 \%$ coupled with carbon dioxide concentrations above $2 \%$ are particularly corrosive ${ }^{47}$. Whilst increasing the flammability or explosion limits of biogas, water vapors causes the lowering of flame temperature, heat values and the stoichiometric or air-fuel ratios of biogas ${ }^{48}$. Removal of water vapor from biogas or dehydration of biogas therefore leads to a reduction in the possibility of corrosion of metallic components, an increase in the heat value of biogas by as much as $10 \%$, as well as increases in both the flame temperature and air-fuel ratio of biogas ${ }^{49}$. Various dehydration methods exist including the use of tri-ethylene glycol (TEG) systems, silica gel and aluminium oxide, air cooling, heating, refrigerant cooling, molecular sieves, calcium chloride ${ }^{505152}$. Water condenses out of the generated biogas due to natural cooling as the gas travels from the generation plant to the consumer. In order to ensure that this condensed water does not clog up the gas line, gas supply lines are designed with a $1 \%$ slope and have condensate traps and condensate drains installed along their length, which are in turn linked to a drainage tank. The condensate traps are designed with increased crosssectional areas and baffle plates to in order to accelerate condensation ${ }^{53}$

Incombustible carbon dioxide reduces the calorific value of biogas, increases its handling requirements and reduces its flame velocity ${ }^{54}$. The content of Carbon Dioxide, which varies as a function of conditions prevailing in a digester and the digester feed composition, introduces constraints on the efficient operation of appliances, such as gas burners ${ }^{56}$. Typical symptoms of carbon dioxide overexposure include dizziness, restlessness, headaches and sweating ${ }^{57}$. Exposure to carbon dioxide in concentrations above the Threshold Limit Value (TLV) time weighted average concentration (TWA) of 5,000 parts per million (ppm) for carbon dioxide that a person may be exposed to continuously for an 8-hour working day, 40-hours working week, and the Threshold Limit Value (TLV) Short Term Exposure Limit (STEL) of 30,000 ppm for carbon dioxide that a person may be exposed to continuously for not more than 15 minutes, even given satisfaction of the 8- hour working day, both cause asphyxiation ${ }^{58}$. It is necessary where possible therefore to remove the gas 
from biogas before storage or use. This however, is only economically viable in cases of commercial production of biogas, due to the related high cost of carbon dioxide removal, as the low biogas production pressure lying between $0.5-2.0 \mathrm{Kpa}$ and the normal operating pressures of appliances of about $0.6-0.7 \mathrm{Kpa}$, requires the use of pumping equipment to circulate the biogas through carbon dioxide scrubbing installations ${ }^{59}$.

Hydrogen sulphide levels in biogas range between $100-4000 \mathrm{ppm}$, with rare cases of $2 \mathrm{ppm}$ and $8000 \mathrm{ppm}$ being recorded now and then ${ }^{60}{ }^{61}$. Hydrogen sulphide not only has an undesirable pungent, "rotten egg" odor in concentrations as low as 50 parts per billion by volume (PPBV) and is toxic in proportions above $10 \mathrm{ppm}$, but is also corrosive and will therefore reduce the life of metallic (copper, iron, steel and lead) pipes, gas holders and other metallic accessories if not removed from biogas ${ }^{62} 63646566$. The corrosive effects Hydrogen sulfide overexposure causes eye irritation and convulsions and is considered a poison in concentrations above 10 and 15 ppm TVL-TWA and TVL-STEL, respectively ${ }^{67}$. Continuous exposure to concentrations of hydrogen sulfide of between $10-50 \mathrm{ppm}$ give rise to nausea, dizziness, headaches and irritation of mucous membranes, while exposure to concentrations of between $200-300 \mathrm{ppm}$ will lead to respiratory arrest, comma or unconsciousness ${ }^{68}$. Exposure to concentrations of hydrogen sulfide in excess of $700 \mathrm{ppm}$, for periods longer than 30 minutes, is likely to result into pulmonary paralysis, sudden collapse and death ${ }^{69}$. When oxidized, hydrogen sulfide forms the sulfur oxides $\mathrm{SO}_{2}$ and $\mathrm{SO}_{3}$ both of which are even more poisonous than hydrogen sulfide. The two oxides form the very highly corrosive sulfuric acid, $\mathrm{H}_{2} \mathrm{SO}_{2}$, and sulfurous acid, $\mathrm{H}_{2} \mathrm{SO}_{3}$, respectively, when exposed to water and occur in the environment as acid rain $^{70} 71$.

A number of processes exist for upgrading of biogas by removal of the undesirable constituents of biogas, hydrogen sulfide and carbon dioxide, including, physical and chemical scrubbing absorption using water or polyethylene glycol and aqueous solvents, respectively ${ }^{72}$ 737475767778 , selective gas permeation through polymeric hollow-fibre membranes or microporous hydrophobic membranes for the high pressure gas separation and low pressure gas liquid absorption processes, respectively, biological desulphurization methods based on aerobic chemotrophic and anaerobic light requiring phototrophic bacteria, combined chemical and biological desulphurization methods, combined water and biological desulphurization methods, insitu methane enrichment, as well as adsorption through granular, large surface area materials such as zeolites, alumina, silica, and activated carbon or silicate molecular sieves $^{79} 808182838485$. The first three methods are poor in separating the two gases removed from methane, while the last method is very efficient and finds wide use in commercial gas upgrading processes. Other methods of separation do exist such as, cryogenic and chemical separation methods, which however are too expensive to be applied to biogas ${ }^{86}{ }^{87}$. Only a few of these methods will be discussed in details and the interested reader is advised to refer to the reference material given here for details on the other methods.

\section{Removal of Carbon Dioxide}

Carbon Dioxide may be removed from biogas by being diffused through water in the ratio of 91.6 $\mathrm{L}$ of water to $200 \mathrm{~L}$ of biogas at a pressure of 1 atmosphere (atm) i.e. $1.015 \times 10^{5} \mathrm{~N} / \mathrm{m}^{2}$ in a counter flow process such as is shown in Figure $2^{88} 89$. The counter flow water spray (or lime water) column method is a variation of this process, in which water with absorbed carbon dioxide from the first column is then sprayed into a desorption column, thus releasing the absorbed carbon dioxide, which is then vented into the atmosphere and the recovered water re-circulated back into the original column ${ }^{919293}$. De-pressurisation or air stripping, of the used water from the first column also achieves the same result ${ }^{94} 9596$. Variations of carbon dioxide absorption scrubbing using water include, multiple or single pressured water / 
biogas counter flow processes, multiple or pressured water / biogas packed bed counter flow systems, each with different levels of efficiency depending on the composition of the raw biogas, water and biogas flow rates and water purity ${ }^{97}$.

Carbon Dioxide may also be removed using aqueous solutions of sodium, potassium and calcium hydroxide, in reactions such as ${ }^{98} 99100$ :

$$
\begin{aligned}
2 \mathrm{NaOH}_{(1)}+\mathrm{CO}_{2(g)} & \longrightarrow \mathrm{Na}_{2} \mathrm{CO}_{3(s)}+\mathrm{H}_{2(l)} \\
\mathrm{Na}_{2} \mathrm{CO}_{3(s)}+\mathrm{CO}_{2(g)}+\mathrm{H}_{2} \mathrm{O}_{(l)} & \longrightarrow 2 \mathrm{NaHCO}_{3(a q)}
\end{aligned}
$$

The hydrogen carbonate obtained, dissociates at temperatures above $150^{\circ} \mathrm{C}$ to give sodium carbonate, which can be used in the manufacture of soap powder or as a chemical reagent in laboratories ${ }^{101}$. Carbon dioxide may also be removed using aqueous solutions of amines such as mono-, di- or tri-ethanolamine. Used mono-, di- or tri-ethanolamine are easily recovered by boiling for about 5 minutes ${ }^{102}$.

\section{Removal of Hydrogen Sulfide}

Hydrogen sulfide is corrosive, poisonous and it combustion by product, sulfur dioxide, is environmentally hazardous ${ }^{103}$. The corrosiveness of hydrogen sulfide increases with increasing concentration, temperature and pressure, and is enhances by the presence of water $^{104}$. The methods used to remove hydrogen sulfide from gas streams fall into the three broad categories of dry oxidation, liquid phase oxidation and formation suppression processes $^{105} 106$. Dry oxidation is either done by the direct introduction of $2-6 \%$ air into the gas stream or by dry adsorption also referred to as chemisorption processes, while liquid phase oxidation may be done either through liquid absorption processes or through the use of oxidizing liquid solutions ${ }^{107} 108109110$. It is important in all processes where biogas gas is mixed with air to ensure that the lower and upper explosive methane concentrations of 5 $15 \%$ by volume in air $^{111}$, also given as $6-12 \%{ }^{112}{ }^{113}$ and $5-20 \%{ }^{114}$, are never reached, otherwise the gas will self ignite without requiring any flame or spark on attainment of its auto-ignition temperature of $343{ }^{0} \mathrm{C}^{115}$.

In dry oxidation processes, the sulfur in hydrogen sulfide is removed from gas through the separate reactions shown below, with iron oxide, iron hydroxide, zinc oxide or alkaline solid particles of different densities and varying degrees of porosity ${ }^{116} 117118119$. Iron oxide for this purpose is normally in the form of iron fillings, iron pellets, iron sponge or steel wool $^{120} 121 \quad 122{ }^{123}{ }^{124}$. The sulfur removal capacities of iron oxide range from $0.20-0.716 \mathrm{~kg}$ of hydrogen sulfide for every one $\mathrm{kg}$ of iron oxide ${ }^{125126}$, also given as $3.7 \mathrm{~kg}$ of sulfur/bushel $\left(0.0352 \mathrm{~m}^{3} \text { of iron oxide }\right)^{127}$. Mixing of the iron fillings with wood shavings or sawdust increases the contact area to volume ratio and therefore enhances scrubbing ${ }^{128} 129{ }^{130}$. The sulfur removal capacities of zinc oxide range from $0.3-0.4 \mathrm{~kg}$ of hydrogen sulfide per $\mathrm{kg}$ of zinc oxide ${ }^{131}$.

$$
\begin{aligned}
& \mathrm{Fe}_{2} \mathrm{O}_{3(s)}+3 \mathrm{H}_{2} \mathrm{~S}_{(g)} \longrightarrow \mathrm{Fe}_{2} \mathrm{~S}_{3(s)}+3 \mathrm{H}_{2} \mathrm{O}_{(l)} \quad \text { Reaction with iron oxide } \\
& 2 \mathrm{Fe}(\mathrm{OH})_{3(s)}+3 \mathrm{H}_{2} \mathrm{~S}_{(\mathrm{g})} \longrightarrow \mathrm{Fe}_{2} \mathrm{~S}_{3(s)}+6 \mathrm{H}_{2} \mathrm{O}_{(l)} \text { Reaction with iron hydroxide } \\
& \mathrm{ZnO}_{(s)}+\mathrm{H}_{2} \mathrm{~S}_{(g)} \longrightarrow \quad \mathrm{ZnS}_{(s)}+3_{2} \mathrm{O}_{(l)} \quad \text { Reaction with zinc oxide } \\
& \left.2 \mathrm{NaOH}_{(a q)}+\mathrm{H}_{2} \mathrm{~S}_{(g)} \longrightarrow \mathrm{Na}_{2} \mathrm{~S}_{(s)}+2 \mathrm{H}_{2} \mathrm{O}_{(l)}\right\} \text { Reactions with alkaline solids } \\
& \mathrm{Ca}(\mathrm{OH})_{2(a q)}+\mathrm{CO}_{2(g)} \longrightarrow \mathrm{CaCO}_{3(s)}+\mathrm{H}_{2} \mathrm{O}_{(l)}
\end{aligned}
$$


Apart from the reaction of iron oxide shown above, several other reactions do occur during scrubbing of biogas with iron oxide, including ${ }^{132}$ :

$$
\begin{array}{llll}
\mathrm{Fe}_{3} \mathrm{O}_{4(s)}+4 \mathrm{H}_{2} \mathrm{~S}_{(g)} & \longrightarrow & 3 \mathrm{FeS}_{(s)}+4 \mathrm{H}_{2} \mathrm{O}_{(l)}+\mathrm{S} & \text { Reaction with iron oxide } \\
\mathrm{Fe}_{3} \mathrm{O}_{4(s)}+6 \mathrm{H}_{2} \mathrm{~S}_{(g)} & \longrightarrow & 3 \mathrm{FeS}_{2(s)}+4 \mathrm{H}_{2} \mathrm{O}_{(l)}+2 \mathrm{H}_{2(g)} & \text { Reaction with iron oxide } \\
\mathrm{FeS}_{(s)}+\mathrm{S}_{(g)} & \longrightarrow & \mathrm{FeS}_{2(s)} & \text { Reaction with iron sulfide }
\end{array}
$$

Iron oxide and hydroxide are regenerated at rates that are lower than the rates of scrubbing by forcing air through the iron sulfide formed during scrubbing, in the reactions ${ }^{133}$ 134135 .

$$
\begin{aligned}
& 2 \mathrm{Fe}_{2} \mathrm{~S}_{3(s)}+3 \mathrm{O}_{2(g)} \longrightarrow 2 \mathrm{Fe}_{2} \mathrm{O}_{3(s)}+6 S_{(g)} \\
& 2 \mathrm{Fe}_{2} \mathrm{~S}_{3(s)}+3 \mathrm{O}_{2(g)}+6 \mathrm{H}_{2} \mathrm{O}_{(l)} \longrightarrow 4 \mathrm{Fe}(\mathrm{OH})_{3(s)}+6 S_{(g)}
\end{aligned}
$$

The regenerated iron oxide and hydroxides are re-used, while the sulfur gas produced is normally released into the atmosphere or may be used as a reagent in laboratories ${ }^{136}$. The iron fillings or steel wool in a sulfur scrubbing column are normally changed once $75 \%$ of the scrubbing iron has been oxidized ${ }^{137} 138$ giving between $3-5$ cycles of use and regeneration ${ }^{139}$. Zinc oxide on the other hand cannot be regenerated and therefore comes with addition disposal costs ${ }^{140}$.

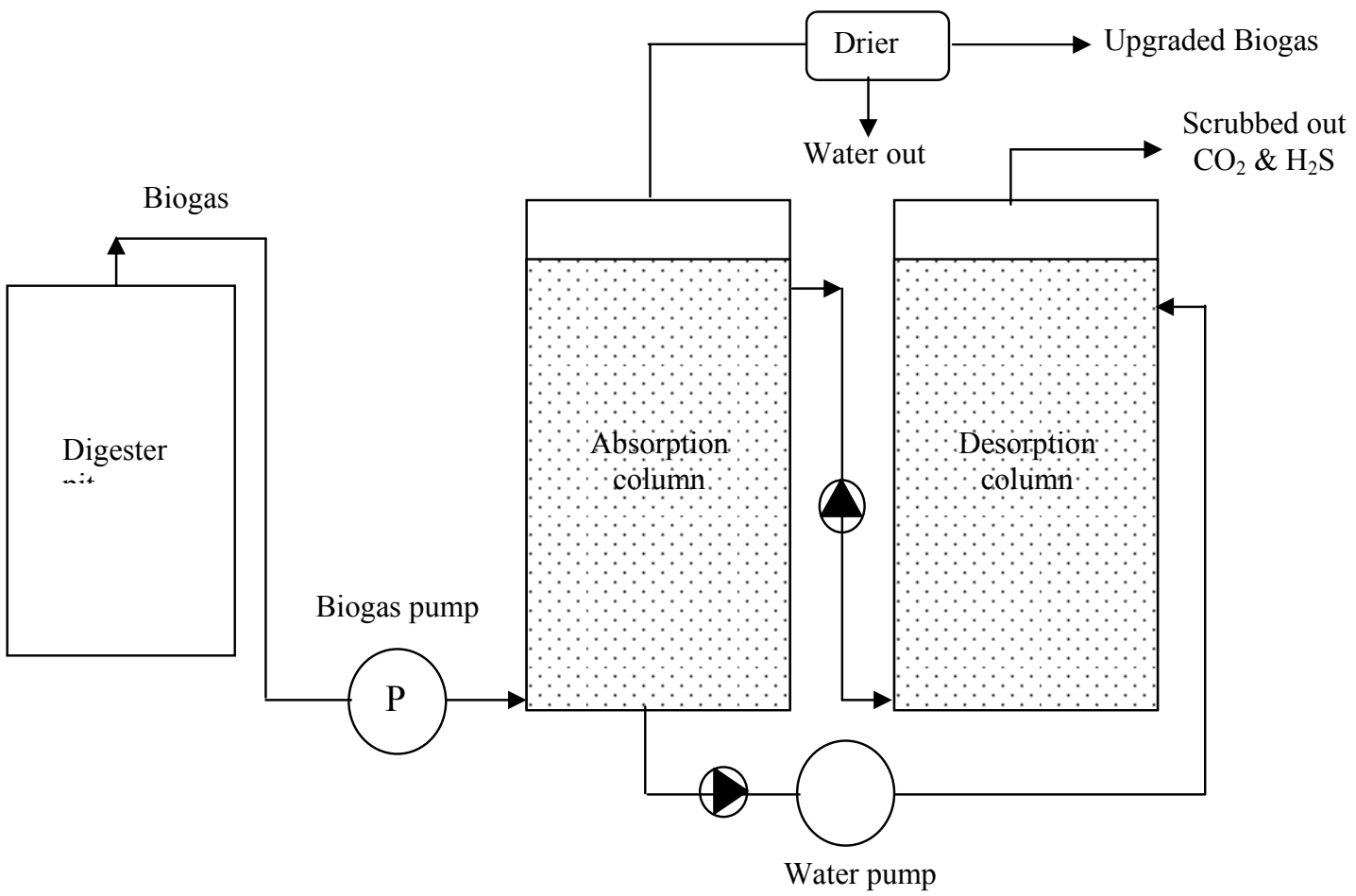

FIGURE 2

WATER-BIOGAS COUNTERFLOW CARONDIOXIDE AND HYGROGEN SULPHIDE DE-PRESSURIZATION SCRUBBING FLOW DIAGRAM 
Figure 2 above shows Liquid scrubbing processes are categorized as being either physical or chemical. Physical liquid scrubbing of hydrogen sulfide is normally done by passing biogas through water, in a process such as is shown in Figure 2 above, with small amounts of sodium hydroxide added in sometimes in order to enhance absorption. The particular system shown here is that of a water-biogas counter flow carbon dioxide and hydrogen sulphide de-pressurization scrubbing plant ${ }^{141}$. The used scrubbing water is recovered using de-pressurization or air stripping processes ${ }^{142}$. Air stripping however does eventually lead to contamination of the scrubbing water with elementary sulfur and is therefore not a preferred method ${ }^{143}$. Chemical liquid absorption scrubbing processes use either iron oxide or zinc oxide slurry, while chemical liquid solution oxidization is based on caustic solution, iron chelate solution, or other iron salt solutions such as iron chloride. In situ hydrogen sulfide control methods include the introduction of chemicals such as ferric chloride and ferrous chloride into digesters, as well as the injection of air or oxygen into the space just above the slurry in a digester ${ }^{144} 145146$.

\section{FACTORS AFFECTING THE PRODUCTION OF BIOGAS AND ITS QUALITY}

Biogas production and its quality are dependent on maintaining a delicate balance between the acid forming and methanogenic bacteria in a digester, which is done through control of several factors including, the type of substrate, the $\mathrm{C} / \mathrm{N}$ ratio of the substrate, temperature, $\mathrm{pH}$, organic loading rate and the concentration of solids in digester charge ${ }^{147} 148$.

\section{Effects of $p H$}

The $\mathrm{pH}$ is the negative logarithm to base 10 of the concentration of hydrogen ions. The $\mathrm{pH}$ in a working biogas plant normally lies between 7 and 8 and the optimum biogas production is achieved for digester inputs with a pH lying between 6 and $7^{149} 150151152153154$. The solids content in biogas digesters should lie between $2-12 \%$ by weight, the rest being water. Solids content lower than $2 \%$ gives rise to reduced production of biogas per unit solids due to a decrease in the active bacteria population in the digester, while solids content higher than $6 \%$ ${ }_{158}$ ay lead to a drop in the quality of biogas produced as a result of increased acidity ${ }^{155} 156157$

Production of biogas in a well designed and properly seeded semi-continuous batch loaded feed unit should start within 24 hours, while a typical batch digester starts producing gas after 2-4 weeks and continues producing for between $3-4$ months ${ }^{159}{ }^{160}$. A maximum production rate after only two days of production from start up and a production of more than $90 \%$ of the total biogas-yield from a grass substrate have been reported after 9 to 11 days of operation of a batch type digester ${ }^{161}$. A continuous feed digester takes between $2-3$ weeks to start producing biogas when started from scratch ${ }^{162}$. Continuous feed digesters may also be started and operated as batch systems till the production of biogas stabilizes in about a week's time $^{163}$. Once production of biogas commences, $1 / 3$ of the total biogas is produced in the first one week, another $1 / 4$ in the second week and the rest in another 6 weeks ${ }^{164}$. Seeding a newly started batch type digester with active sewage waste whose volume is $15 \%$ of that of the digester, reduces the stabilization period of methanogenic bacteria to a point where optimum gas production is achieved, from between $2-3$ months to 4 weeks ${ }^{165} 166167$.

In a balanced digester, the action of methanogenic bacteria that feed on acids formed by acetogenic bacteria, helps maintain a neutral pH of slurry to $8^{168} 169170171{ }^{172}$. Digestion of nitrogen by the methanogens produces ammonia, $\mathrm{NH}_{4}$, which increases the $\mathrm{pH}$ of slurry ${ }^{173}$. A 
$\mathrm{pH}$ value that is higher than 8.5 is toxic to the methanogenic bacteria ${ }^{174}$. In a newly started digester however, the acid forming bacteria become active before the methanogens. This coupled with the fact that the reaction rate involving acid forming bacteria is faster than the one involving methanogens, normally leads to an initial reduction of the slurry $\mathrm{pH}$ to below $7^{175}{ }^{176}$. Moreover, methanogic bacteria take time to multiply to the numbers required to maintain a stable production of methane. It is necessary therefore to buffer a newly started digester using baking soda (sodium bicarbonate $-\mathrm{NaHCO}_{3}$ ), lime (calcium oxide $-\mathrm{CaO}$ ), or ammonium hydroxide $\left(\mathrm{NH}_{4} \mathrm{OH}\right)$ in order maintain the $\mathrm{pH}$ within a range that is conducive for methanogenic bacteria to operate ${ }^{177} 178179$. The activity of methanogenic bacteria begins to become inhibited at a $\mathrm{pH}$ of $6.6^{180} 181$ and $\mathrm{pH}$ values below 6 are clear indication that too much acid is being formed as a result of too few methanogenic bacteria. $\mathrm{PH}$ values above 5 though low can be corrected by the addition of lime or dilution of the digester feed ${ }^{182}{ }^{183}$. PH values below 5 on the other hand, will almost certainly lead to a stoppage of digesters, which then requires a complete replacement of the slurry and a fresh restart ${ }^{184}$.

\section{Effects of Toxins}

Toxic substances such as antibiotics, disinfectants and pesticides are designed to kill bacteria and will also stop the digester from functioning. Detergents have a similar effect, therefore if a cattle shed from which the feedstock is obtained, is washed with detergents, it must subsequently be rinsed thoroughly with clean water ${ }^{185}$.

\section{Effects of Temperature}

Bacteria may be classified by their preferred operating temperatures:

- Cryophilic (Psychrophilic) bacteria work best at temperatures between $10^{\circ} \mathrm{C}$ and $20^{\circ} \mathrm{C}$.

- Mesophilic bacteria work best at temperatures between $20^{\circ} \mathrm{C}$ and $40^{\circ} \mathrm{C}$.

- Thermophilic bacteria work best at temperatures between $40^{\circ} \mathrm{C}$ and $60^{\circ} \mathrm{C}$.

While anaerobic digestion is very efficient in thermophilic regions, digesters in the tropics may operate adequately in the mesophilic region. Gas production efficiency, which is the gas produced per unit kilogram of feedstock, generally increases with temperature, roughly doubling for every $10^{\circ} \mathrm{C}$ rise between $15^{\circ} \mathrm{C}$ and $35^{\circ} \mathrm{C}^{186}$. The quantity of ammonia, in a digester increases with increasing temperature, which because of its inhibitory effect on methanogenic bacteria as a result of increasing $\mathrm{pH}$ activity, leads to a decrease in the production of biogas ${ }^{187}$. High digester operating temperatures in digesters are therefore preferable, for so long as the production of ammonia is limited. Methanogenic bacteria are also known to be very sensitive to temperature changes, the degree of sensitivity being dependent on the range of temperature change. Changes in temperature of less than $\pm 2{ }^{0} \mathrm{C} / \mathrm{h}$, $\pm 1^{0} \mathrm{C} / \mathrm{h}$ and $\pm 0.5^{\circ} \mathrm{C} / \mathrm{h}$ in the cryophilic, mesophilic and thermophilic anaerobic temperature ranges, respectively, are considered to be un-inhibitive ${ }^{188}$. A sudden change of more than $5^{\circ} \mathrm{C} /$ day day may cause a digester to stop working temporarily resulting in accumulation of volatile acids and eventual stalling of the digester. This phenomenon is less of a problem in large digesters where, the high heat capacity of the slurry ensures that the digester temperature changes slowly ${ }^{189}$. Figure 3 shows the various operating temperatures and production rates of biogas for various types of bacteria ${ }^{190}$. 


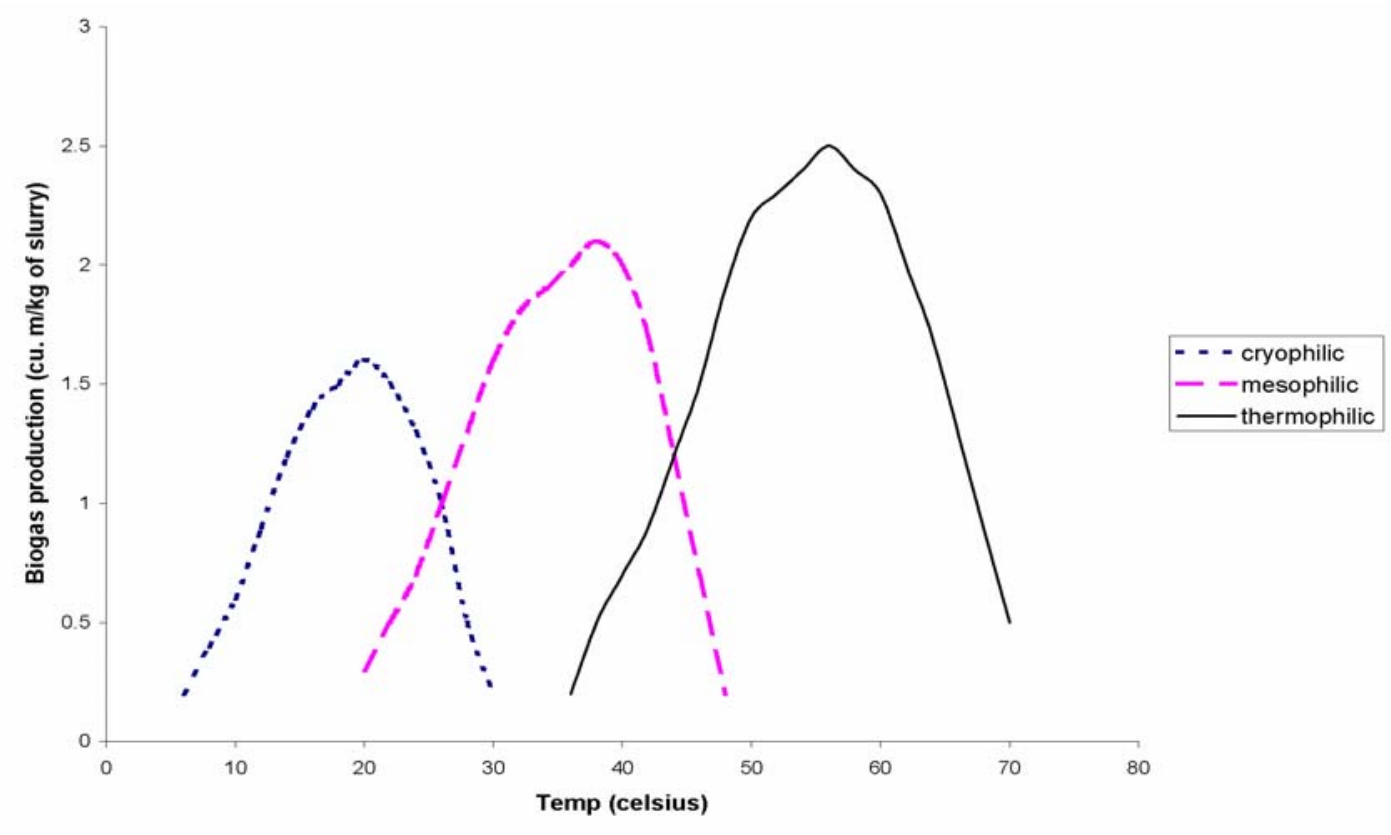

FIGURE 3

OPERATING TEMPERATURES AND PRODUCTION RATES OF VARIOIUS TYPES OF BACTERIA ${ }^{191}$

\section{Properties of Feedstock}

Any material containing food substances comprising of carbohydrates, proteins and fats, can be digested in a biogas plant. However, the rate and efficiency of digestion of the feedstock depends on their specific physical and chemical form, thus:

- Cattle dung is the easiest feedstock to use for a biogas plant as it already contains the right types of bacteria and is already broken down chemically by acids and enzymes in the animals gut ${ }^{192}$.

- Human, pig and chicken manure are also good but need a 'starter' such as slurry from a working biogas plant to initiate the digestion process.

- Goat and sheep dung are rich in nutrients but occur in the form of pellets and therefore need to be broken down mechanically to make them easily soluble in water and hence digestible by the bacteria.

- Raw vegetable must be broken down first before being used. This can be done physically through chopping or mincing ${ }^{193}$.

\section{Carbon and Nitrogen (C/N) Ratio}

$\mathrm{C} / \mathrm{N}$ ratio is an important parameter in biogas production since anaerobic bacteria need nitrogen for growth, however, if not properly controlled, it can inhibit methanogenic activity. The optimum $\mathrm{C} / \mathrm{N}$ ratio for a digester lies in the range $20-30: 1$. $\mathrm{C} / \mathrm{N}$ ratios that are too high inhibit the production of biogas as the nitrogen levels are too low for the production of new cell structures by the methanogenic bacterial required to replicate themselves. Low $\mathrm{C} / \mathrm{N}$ ratios on the other hand inhibit methanogenic acitivity due to the production of excess amounts of ammonium that may lead to an increase in the alkalinity of a digester beyond the tolerable $\mathrm{pH}$ level of $8.5^{194} 195196197198199$. Where cattle or sewage slurry is used, this ratio is maintained naturally due to the composition of the feedstock. In case the ratio falls, it can be raised by 
adding components with a high $\mathrm{C} / \mathrm{N}$ ratio such as saw dust into the digester slurry. The dry weight of nitrogen as a percentage of the feedstock weight and $\mathrm{C} / \mathrm{N}$ ratios of some selected feedstock are shown in Table II below.

TABLE II

DRY WEIGHT OF NITROGEN AND C/N RATIOS SOF SELECTED FEEDSTOCK ${ }^{200}$.

\begin{tabular}{ccc}
\hline Material & $\begin{array}{c}\mathrm{N} \\
(\%)\end{array}$ & $\begin{array}{c}\mathrm{C} / \mathrm{N} \\
\text { Ratio }\end{array}$ \\
\hline Animal & 1.8 & 19.9 \\
Dung cow & 2.3 & 25 \\
horse & 6.3 & 7.3 \\
chicken & & \\
Household Waste & 7.1 & 6.72 \\
night soil & 1.9 & 28.6 \\
kitchen waste & & \\
Crop Residual & & \\
crop stalks & 1.2 & 50.6 \\
rice straw & 0.7 & 51.0 \\
corn cobs & 1.0 & 49.9 \\
Others & & \\
saw dust & 0.1 & $200-500$ \\
grass trimmings & 2.5 & 15.7 \\
\hline
\end{tabular}

TYPES OF BIOGAS DESIGNS

There are different types of biogas digester designs:

- Floating gas drum design.

- Fixed dome design.

- Flexible bag design.

- Slurry pit with flexible gas cover design.

A suitable Biogas design must be amendable to production in different sizes and be adaptable to the customer's specifications. In this paper, we shall consider three designs namely, the floating drum design, fixed dome design and the flexible bag design.

\section{Floating Gas Drum Biogas Design}

In this type of biogas design, the slurry is kept in a cylindrical pit in the ground. The pit is lined with bricks that are supported by the surrounding soil to ensure that the plant is able to withstand hydraulic pressure from the feed slurry. The gas is normally collected in a cylindrical steel gas drum that floats mouth downwards in the slurry. Figure 5 shows a typical floating drum digester design.

As the gas rises through the slurry, it carries some of the lighter slurry particles which settle at the top of the slurry to form scum that inhibits the biogas from passing through ${ }^{201}$. Problems of scum formation are particularly prevalent in digesters that are charged with vegetable waste and it is important though not necessary therefore to have a stirring and mixing mechanism installed in digesters, particularly for batch type of digester systems ${ }^{202}$. 
Where the digester substrate consists primarily of solute substances, there is no formation of scam ${ }^{203}$. Continuous feed systems on the other hand experience automatic and continuous break up any scam formed as the new feed comes into the digester ${ }^{204}$. Thin layers of scum will not normally inhibit the release of biogas and in cases of substrates with high Total Solids (TS) content, no stratification occurs ${ }^{205}$. Stirrers and mixers will normally be used daily, in order to facilitate removal of the biogas produced, for purposes of inoculation of the fresh substrate with bacterial in the digester, break up scum and avoid sedimentation by keeping the heavy material distributed in the digester system and to ensure a uniform distribution of bacterial in the digester by avoiding the formation of areas of low bacterial activity due to local depletion of nutrients and concentration of metabolic products 206207208 209210 . There is not hard and fast rule determining the regularity and degree of stirring, which varies from digester to digester and from substrate to substrate, and may if excessive inhibit the process of digestion ${ }^{211}$.

The gas collection drum usually has a steel bar framework fixed on its lower inner side, which serves to stir up and break up any scum that is formed, when the drum is rotated $^{212}$ using brackets that are fixed on its inclined outer surface. The gas drum is held in a vertical position by a central guide pipe running vertically through a second pipe at its center. This system allows the drum to move up and down and to rotate about its axis, without tipping $^{213}$. The facility of the gas drum to move up and down regulates the pressure of the produced gas at a constant value, while its ability to rotate helps break up any scum formed on the surface of the digester slurry. The floating gas drum biogas system falls in the category of continuous biogas systems, in which the slurry in the digester is displaced into the effluent chamber by incoming slurry. There is need in such types of biogas systems, to ensure that slurry that is fed into digesters is well mixed and that it carries little or no inorganic material such as sand and stones, in order to avoid sedimentation and the related gradual reduction of the digester capacity ${ }^{214}$. In the event of large volumes of sand and stones accumulating at the bottom of the digester, it would be necessary to stop operation of the digester and then manually empty out the slurry, together with any deposited sand and stones.

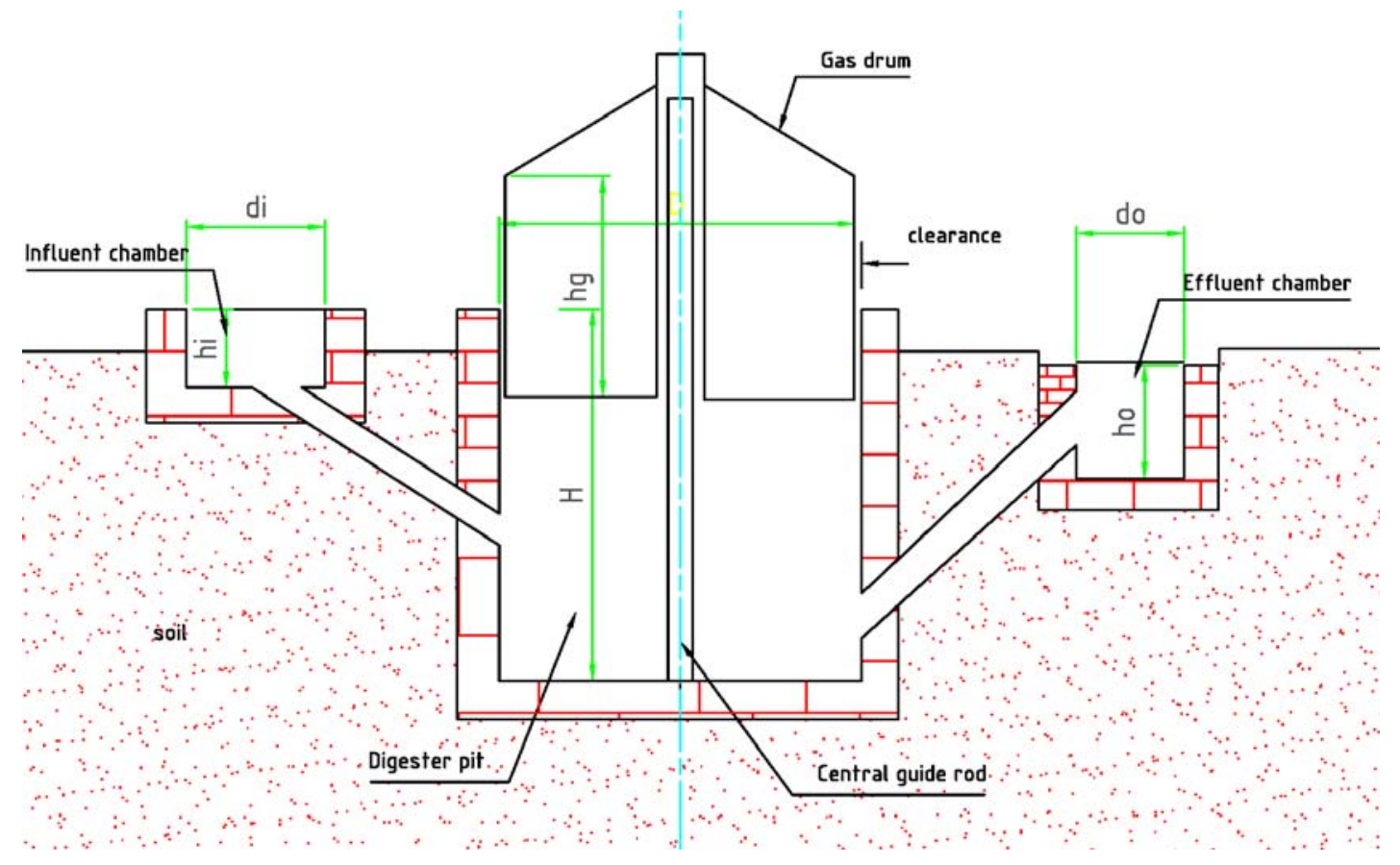




\section{FIGURE 5}

FLOATING DRUM BIOGAS DIGESTER ${ }^{215}$

\section{Fixed Dome Biogas Design}

This type of biogas design consists of a digester pit lined with bricks and a permanent concrete roof placed over it. Earth soil is piled on top of the roof in order to assist in containing the gas produced within it. As the gas is produced, it collects in the dome and displaces some of the slurry from the digester pit to the effluent chamber. The slurry flows from the influent chamber into the digester pit where it is used up in production of biogas. Access into the digester pit during part of the construction and cleaning is solely through the slurry influent and effluent chambers. This makes the fixed dome biogas design difficult to maintain and operate ${ }^{216}$. Figure 6 shows a typical fixed dome biogas design.

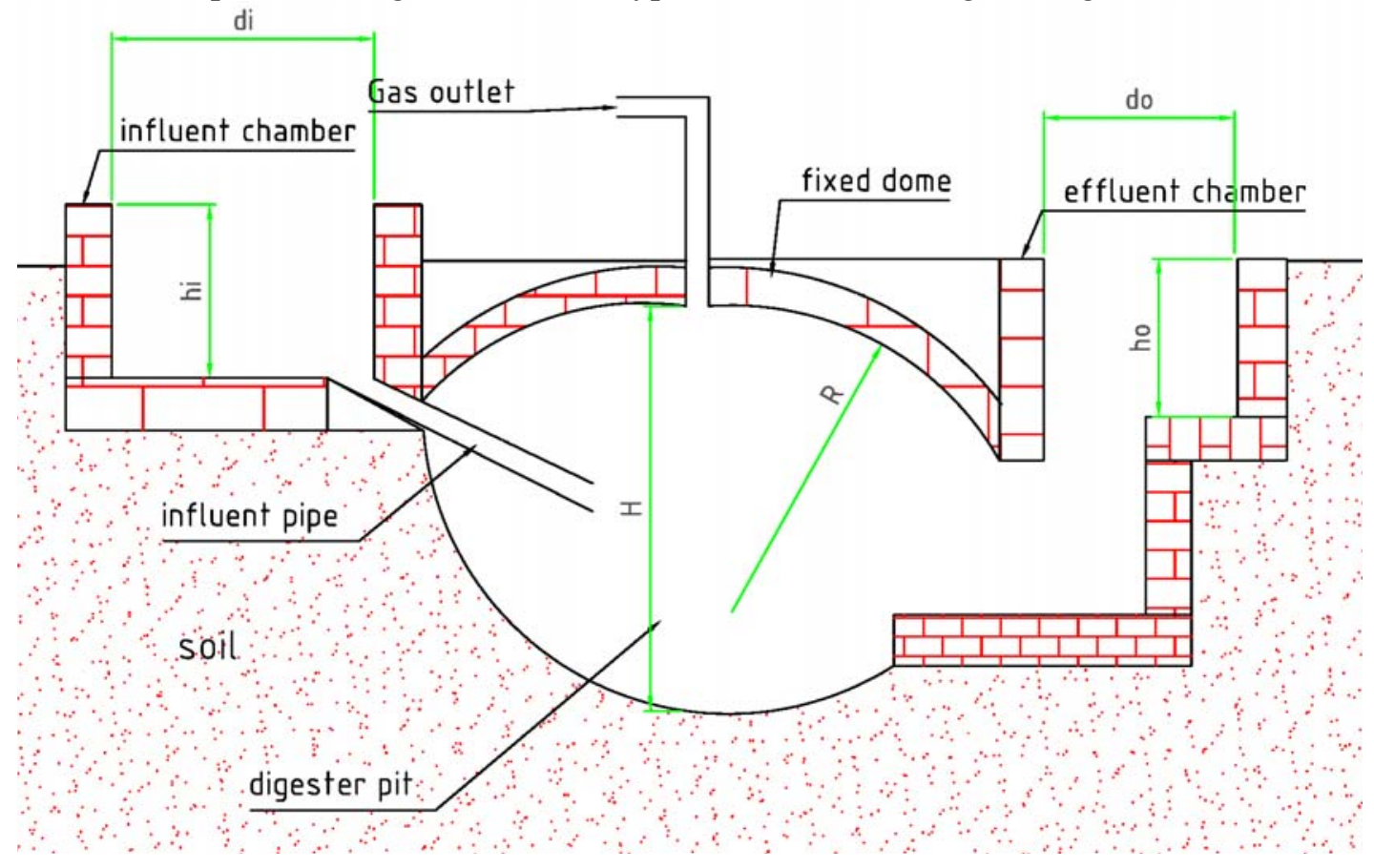

FIGURE 6

FIXED DOME DIGESTER

\section{Flexible Bag Biogas Design}

This type of biogas design consists of a long cylindrical bag, made of plastic material that is placed in a trench, which is lined with masonry, compacted sand or mud. The slurry fills the lower $2 / 3$ of the bag and the gas collects above it. As the biogas is used up, the bag collapses behaving like a balloon. The edges of the roof are held down to the edges of the trench with clips or poles passing through loops in the plastic bag.

The major limitation with this design is the difficulty in tapping the gas produced. A flexible PVC pipe can be welded on the top of the bag for collection of the gas but it is not easy to ensure an air-tight seal between the pipe and the plastic bag. In addition, there is a risk of explosion in case of excess gas pressure ${ }^{217}$. Figure 7 shows a typical flexible bag biogas design. 


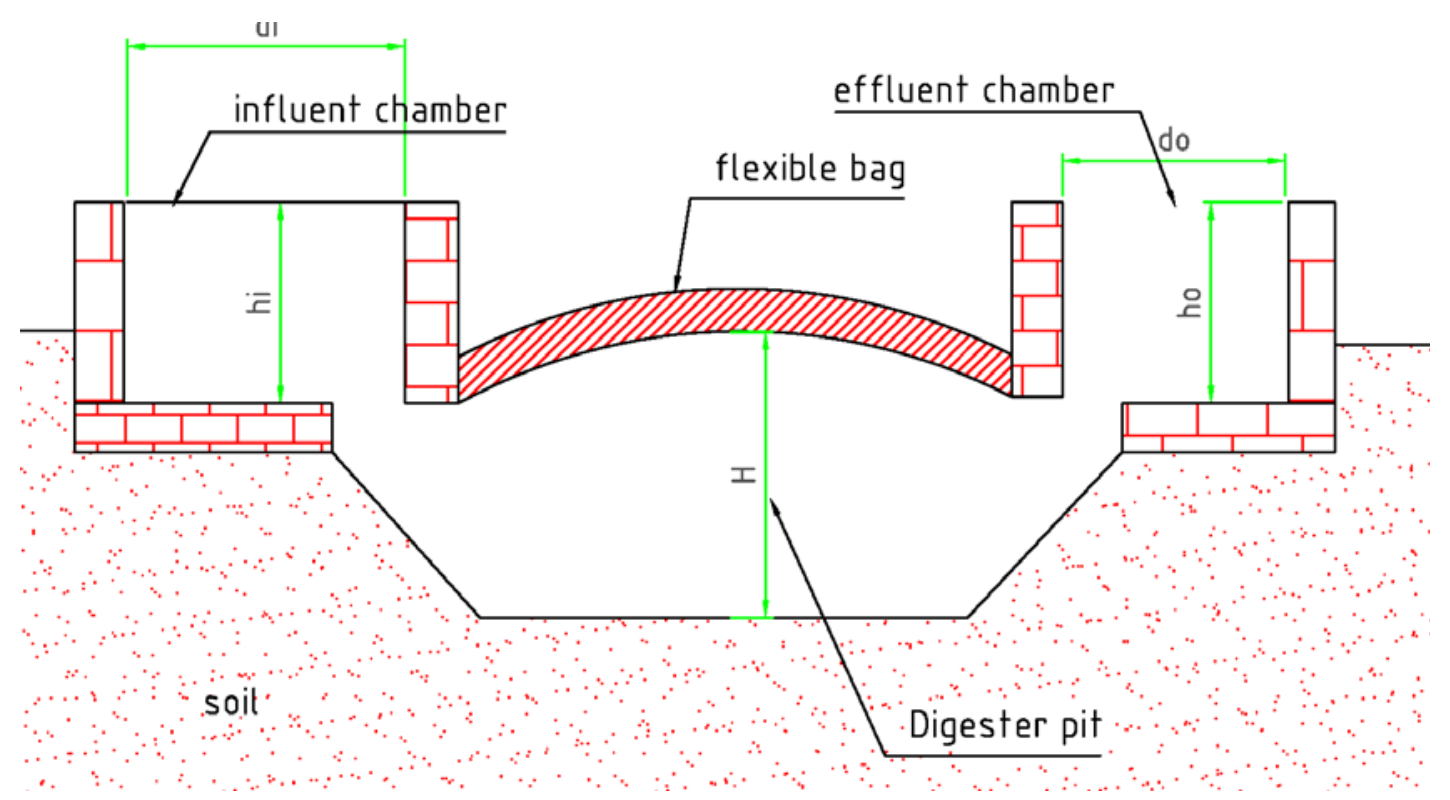

FIGURE 7

FLEXIBLE BAG DIGESTER

Effluence in the effluent tanks is very useful as a fertilizer as it provides a good source of organic material to help maintain or increase the humus content of soils, which in turn helps maintain or improve the soil structure ${ }^{218} 219$. Further usefulness of the effluence arises from the fact that it contains water soluble nitrogen, a plant nutrient, that can be readily taken in by plants ${ }^{220}$. The nitrogen in the effluence occurs in the form of ammonia and is highly volatile, which makes it necessary to be fed directly at plants bases, preferably by being transmitted under the soil surface in order to minimize loss through vaporization in the process $^{221} 222$. The effluence may be fed through channels to a sloping filter bed on the ground that is covered with a layer of compacted dry or green leaves of about $15 \mathrm{~cm}$ that acts to filter the solids off ${ }^{223}$. The solids can then be carried off for spreading on farms around plants, while the liquid can either be mixed with fresh digester charge solids to form slurry or is pumped directly to the bases of plants ${ }^{224}$. Effluent slurry may alternatively be channeled out to basins that are lined with plastic sheeting in order to prevent loss of the liquid by percolation through the soil and whose surface on filling with the effluence is then covered with a mixture of soil and leaves in order to minimize evaporation loss of nitrogen 22622 . The mixture is then taken out and spread in the farm around plant material when needed ${ }^{228}$. Plants that have been treated with digester effluence have shown increases in yield of $5-20 \%$ compared to crops not treated this way ${ }^{229} 230$, thus emphasizing the importance of utilizing digester effluence on plants.

\section{BASIS OF SELECTING A BIOGAS PLANT DESIGN}

The choice of a particular biogas design must be guided by comparison of the various available options and based on criteria that weigh their respective strengths and weaknesses. In the present work, the choice of a particular type of biogas design was informed by comparing the following factors, each on a scale of 0 to 10 . 
- Strength - can the design withstand the gas pressure as well as the hydraulic pressure of the slurry?

- Cost of construction.

- Availability and cost of the materials.

- Ease of construction.

- Ease of operation.

- Ease of maintenance.

- Reliability - can it function as expected and with what regularity?

- Gas tight - can it accommodate the gas pressure without leakage?

- Safety - is it safe to operate the plant, is it safe from explosions?

Table III shows the rating of the three designs selected here for comparison against the above factors based on a $0-10$ scale, 0 -lowest and 10-highest.

TABLE III

COMPARISON OF THREE SELECTED, BIOGAS DESIGNS.

\begin{tabular}{cccc}
\hline & $\begin{array}{c}\text { Floating gas drum biogas } \\
\text { design }\end{array}$ & $\begin{array}{c}\text { Fixed dome biogas } \\
\text { design }\end{array}$ & $\begin{array}{c}\text { Flexible bag biogas } \\
\text { design }\end{array}$ \\
\hline Strength & 8 & 9 & 5 \\
Cost of construction & 6 & 7 & 8 \\
Availability of materials & 9 & 9 & 6 \\
Ease of construction & 8 & 5 & 6 \\
Ease of operation & 9 & 7 & 7 \\
Ease of maintenance & 8 & 4 & 5 \\
Reliability & 8 & 7 & 7 \\
Safety & 8 & 5 & 7 \\
Gas tight & 7 & 6 & 5 \\
Total & $\mathbf{7 1}$ & $\mathbf{5 8}$ & $\mathbf{5 5}$ \\
\hline
\end{tabular}

The floating gas drum biogas design comes out with the highest total score in Table 2, thus making it the best of option of the three. The following factors further make the floating gas drum more attractive:

- Ease of maintenance - the gas holder can be removed easily thus giving easy access for inspection and repair of the digester and gas holder as well as repainting for the cache.

- In case of the plant stalling, the gas holder can be removed easily and the digester cleaned.

- It is easy to incorporate a slurry mixing mechanism in a floating gas holder system.

- Amongst the factors that make fixed dome and flexible plastic bag, biogas designs unattractive include:

- Need for gas tight coatings or plastic liners, applied to the walls of the dome in order to prevent gas leakage through pores in the building materials.

- Lack of direct access to the digester pit for the fixed dome design in the event of the plant stalling.

- Possibility of collapse of concrete domes. 
- Possibility of explosion of the concrete domes and flexible plastic bag due to excessive biogas pressure.

- Effective sealing between the flexible plastic bag and the gas outlet pipe is difficult to achieve.

\section{MODIFIED FLOATING DRUM BIOGAS UNIT}

The ensuing work is all based on the floating gas drum biogas design. Various modifications can be made on the standard floating gas drum biogas design such as:

- Extension of the gas drum roof to cover the digester pit. This prevents rain water from entering the digester pit to avoid the diluting the slurry ${ }^{231}$.

- Protrusion of the effluent pipe into and at the top of the effluent chamber to prevent the effluent from flowing back into the digester pit ${ }^{232}$.

- Construction of a partition wall in the digester, which is raised above the influent pipe in order to ensure that the incoming slurry does not feed directly into the effluent pipe, thereby passing right through the digester without being digested ${ }^{233}$.

- In the absence of the partition wall, an angle of between $90^{\circ}$ and $135^{\circ}$ in plan view, between the digester inlet and outlet pipes must be maintained in order to minimize incidences of incoming slurry feeding directly into the effluent pipe, and therefore passing right through the digester without digestion ${ }^{234}$.

- The entry height of the influent pipe, above the digester floor and the effluent pipe intake, prevents the slurry already in the digester from blocking the influent pipe.

Figure 8 shows the modified floating drum biogas digester.

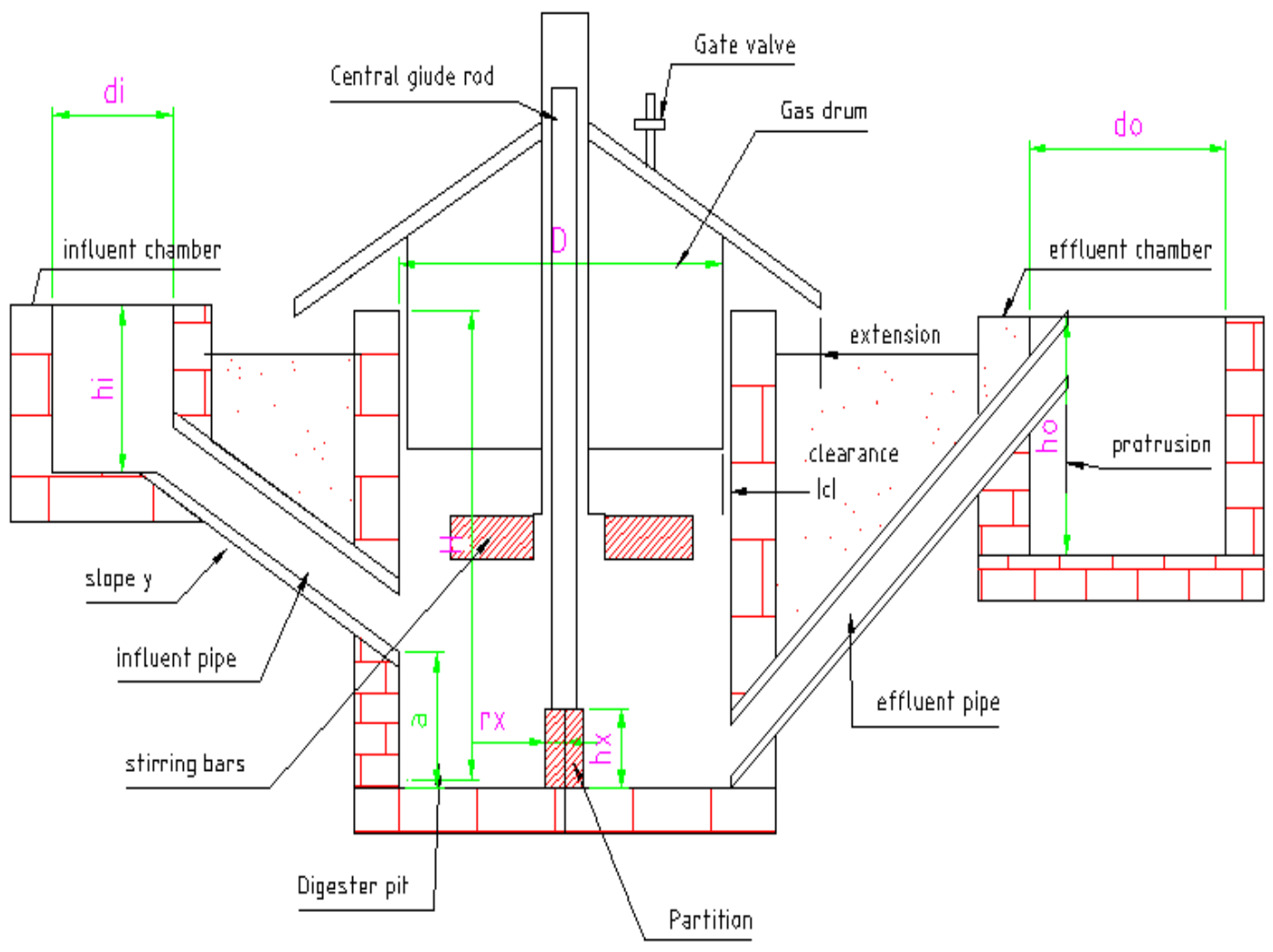

FIGURE 8 


\section{DIGESTER SIZING}

The main variable that controls the design of a biogas unit is the internal volume of the digester, since the amount of the gas produced is a function of the volume of slurry in the digester pit. The digester volume is mainly dependent on the slurry feed rate and retention time and ultimately therefore, on the amount of slurry available. Slurry loading rates are easily converted into total volatile solids (TVS) per day per unit volume of the digester or the weight of TVS added per day per weight of TVS already in the digester from set ratios of dilution of solids with water that are dependent on the type and dryness or wetness status of a particular substrate 235236237 .

\section{Retention Time}

The retention time $\mathrm{R}$ is the time that the slurry requires to stay in the digester pit for complete digestion by bacteria. For continuous digester systems, the daily feed rate (v) is arrived at by dividing the digester volume $\left(V_{d}\right)$ with the slurry retention time $(R)$, thus:

$$
v=\frac{V_{d}}{R}
$$

The retention time is dependent on the prevailing temperature in a digester and on the type of substrate used. Most biogas digesters in Kenya operate in the mesophilic temperature range $\left(20^{\circ}<\mathrm{t}<40^{\circ} \mathrm{C}\right)$. For liquid manure undergoing fermentation in this temperature range, the following approximate retention times apply ${ }^{238}$ :

- Liquid cow manure 20 - 30 days

- Liquid pig manure 15 - 25 days

- Liquid chicken droppings 20 - 40 days

Various experiments on the retention time that have been carried out on cow dung slurry show that biogas production starts dropping on the 40th day ${ }^{239}$. For the analysis presented here, a retention time of 50 days was chosen in order to allow for the complete digestion of cow dung slurry. The feed rate in such a case is easily calculated from equation 1.

The feed rate is of course dependent on the amount of manure available, which translates to the number of cows and volume of water available. The optimum water:cow manure volume ratio is $0.7: 1.0^{240}$. Of course the wetter or drier manure is the less or more extra water is required to be added. The optimum solids content and effects of charging digesters with slurries whose solids contents are outside the optimum range have been discussed in the section entitled, "Effects of $\mathrm{pH}$ ".

\section{SIZING OF DIGESTER PITS AND GAS HOLDERS}

The following standard relationships were used in order to size the biogas units based on a zero grazed $\operatorname{cow}^{241}$ :

- $1 \mathrm{~kg}$ of cow dung is mixed into $1.8 \mathrm{~L}$ of slurry.

- 1 cow produces $10 \mathrm{~kg}$ of cow dung per day. 
- $1 \mathrm{~kg}$ of cow dung produces $0.062 \mathrm{~m}^{3}$ of methane gas.

- 1 person requires $(0.34-0.42) \mathrm{m}^{3}$ of methane gas per day.

- $(0.34-0.42) \mathrm{m}^{3}$ of methane gas requires $(5.48-6.77) \mathrm{kg}$ of cow dung per day.

Table IV below shows the sizes of digesters and gas holders that are determined from these relationships.

TABLE IV

SIZING OF DIGESTERS AND GAS HOLDERS

\begin{tabular}{cccccc}
\hline Cows & $\begin{array}{c}\text { Amount of biogas } \\
(\mathrm{No})\end{array}$ & $\begin{array}{c}\text { Amount of wet dung } \\
\left(\mathrm{m}^{3}\right)\end{array}$ & $\begin{array}{c}\text { Persons } \\
(\mathrm{kg})\end{array}$ & $\begin{array}{c}\text { Digester size } \\
(\mathrm{No})\end{array}$ & $\begin{array}{c}\text { Gas holder size } \\
\left(\mathrm{m}^{3}\right)\end{array}$ \\
\hline 1 & 0.57 & 5.48 & 1 & 0.49 & 0.25 \\
3 & 2.83 & 27.40 & 5 & 2.45 & 1.25 \\
6 & 5.67 & 54.80 & 10 & 4.9 & 2.50 \\
8 & 8.50 & 82.25 & 15 & 7.35 & 3.75 \\
11 & 11.33 & 109.6 & 20 & 9.80 & 5.00 \\
14 & 14.17 & 137.00 & 25 & 12.25 & 6.25 \\
17 & 17.00 & 164.00 & 30 & 14.70 & 7.50 \\
20 & 20.67 & 200.00 & 35 & 18.00 & 9.00 \\
\hline
\end{tabular}

\section{Dimensioning}

In determining the dimensions of digesters, the simplifying assumption was made here that the diameter of the digester $(D)$ is equal to its height $(H)$. A clearance gap of $20 \mathrm{~mm}$ between the digester pit and the gas drum was adopted as adequate to allow free rotation of the gas drum, without allowing too much leakage of the generated gas. The volume of such a digester pit is given by:

$$
V_{d}=\frac{\pi D^{2} H}{4}
$$

which since $H \approx D$ becomes:

$$
V_{d}=\frac{\pi D^{3}}{4}
$$

From which the diameter of the digester is obtained as:

$$
D=\sqrt[3]{\frac{4 V_{d}}{\pi}}
$$

Taking the gas holder/digester radial clearance to be $20 \mathrm{~mm}$, gives a diameter (d) of the gas holder of: 


$$
d=(D-0.04)=\left(\sqrt[3]{\frac{4 V_{d}}{\pi}-0.04}\right) \mathrm{m}
$$

by:

Given a gas holder volume $\left(\mathrm{V}_{\mathrm{g}}\right)$, the height $(\mathrm{h})$ of the gas holder is therefore be given

$$
h=\frac{4 V_{g}}{\pi d^{2}}=\frac{4 V_{g}}{\pi}\left(\sqrt[3]{\frac{4 V_{d}}{\pi}-0.04}\right)^{-2} \mathrm{~m}
$$

Table $\mathrm{V}$ below gives the dimensions of the digester pit and gas holder based on Equations 3-6 ${ }^{242}$.

TABLE V

\begin{tabular}{|c|c|c|c|c|c|c|}
\hline $\begin{array}{l}\text { Cows } \\
\text { (No.) }\end{array}$ & $\begin{array}{c}\mathrm{V}_{\mathrm{d}} \\
\left(\mathrm{m}^{3}\right)\end{array}$ & $\begin{array}{c}\mathrm{D} \\
(\mathrm{m})\end{array}$ & $\begin{array}{c}\mathrm{H} \\
(\mathrm{m})\end{array}$ & $\begin{array}{c}\mathrm{V}_{\mathrm{g}} \\
\left(\mathrm{m}^{3}\right)\end{array}$ & $\begin{array}{c}\mathrm{D} \\
(\mathrm{m})\end{array}$ & $\begin{array}{c}\mathrm{H} \\
(\mathrm{m})\end{array}$ \\
\hline 1 & 0.49 & 0.85 & 0.85 & 0.25 & 0.81 & 0.49 \\
\hline 3 & 2.45 & 1.46 & 1.46 & 1.25 & 1.42 & 0.79 \\
\hline 6 & 4.90 & 1.84 & 1.84 & 2.50 & 1.80 & 0.98 \\
\hline 8 & 7.35 & 2.11 & 2.11 & 3.75 & 2.07 & 1.11 \\
\hline 11 & 9.80 & 2.32 & 2.32 & 5.00 & 2.28 & 1.22 \\
\hline 14 & 12.25 & 2.50 & 2.50 & 6.25 & 2.46 & 1.31 \\
\hline 17 & 14.70 & 2.66 & 2.66 & 7.50 & 2.62 & 1.39 \\
\hline
\end{tabular}

DIMENSIONS OF DIGESTERS AND GAS DRUMS

COSTING OF THE BUILDING MATERIALS AND LABOR

\section{Costs of materials for the digester pit}

Mortar, a mixture of sand, cement and water, to be used in joining stones and also for the digester inner wall plastering should be in the ratio of: 1 part of cement, 6 parts of sand, 7 parts of water. Concrete, a mixture of sand, cement, ballast and water, to be used in constructing the digester floor, should be in the ratio of: 1 part of cement, 2 parts of sand, 4 parts of ballast and 5 parts of water. A layer of stones is referred to here as a course, as is the norm.

The number of stones $\left(N_{s}\right)$ per course in given by:

$$
N_{c}=\frac{H}{h_{s}}+1
$$

Number of courses of stone required $\left(N_{c s}\right)$ is given by: 


$$
N_{c s}=\frac{2 \pi R}{l}, \text { where } R=\frac{(D+b)}{2}
$$

The symbols $H, h_{s}, R, l, D$ and $b$ are as defined in the section on nomenclature.

The total number of stones $\left(N_{T}\right)$ required therefore is given by:

$$
N_{T}=\frac{2 \pi R}{l}\left(\frac{H}{h_{s}}+1\right)
$$

The quantity of mortar $\left(Q_{m}\right)$ required is given by:

$$
Q_{m}=\left(2 \pi R \times b \times k \times N_{c}\right)+\left(N_{s} \times k \times b \times h_{s}\right)+(D \times H \times k)
$$

The amount of concrete $\left(Q_{\mathrm{c}}\right)$ required is given by:

$$
Q_{c}=\frac{\pi}{4\left[\left(d_{i}+2 b\right)^{2} t+\left(d_{o}=2 b\right)^{2} t+(D+2 b) 2 t+d_{x}^{2} h_{x}\right]}
$$

Where the symbols $d_{i}, d_{o}, d_{x}, h_{x}$ and $t$ are as defined in the section on nomenclature.

Since building materials are normally sold in weight, it was necessary to use the values of density given in Table VI below to compute the weight of these materials ${ }^{243}$.

TABLE VI

MATERIAL DENSITIES (COURTESY OF CIVIL ENGINEERING DEPARTMENT, JKUAT)

\begin{tabular}{cc}
\hline Material & Density $\left(\mathrm{kg} / \mathrm{m}^{3}\right)$ \\
\hline cement & 1440 \\
sand & 1445 \\
ballast & 1450 \\
\hline
\end{tabular}

In order to compute costs for the building materials, a quotation of the materials was obtained from a local hardware and building materials dealer (Tumaine Hardware, P.O. Box 288, Kalimoni, Kenya), as shown in Table VII below.

TABLE VII

PRICE LIST FOR BUILDING MATERIALS

\begin{tabular}{lllc}
\hline \multicolumn{1}{c}{ Item } & Description & Units & Unit cost \\
& & & $($ Kshs $)$ \\
\hline mild steel rods & $\mathrm{d}=25 \mathrm{~mm}$ & $\mathrm{kgs}$ & 240 \\
mild steel sheet ofsheet & gauge $14(3 \mathrm{~mm})$ & sheet & 1590 \\
mild steel electrodes & $\mathrm{d}=2.5 \mathrm{~mm}$ & packet & 680 \\
GI pipe & $\mathrm{d}=1 "$ & metres & 240 \\
PVC pipe & $\mathrm{d}=6 ", 1=6 \mathrm{~m}$ & metres & 1850 \\
dressed stones & standard & pieces & 26 \\
\hline
\end{tabular}




\begin{tabular}{|c|c|c|c|}
\hline Sand & & tons & 1200 \\
\hline ballast & & tons & 1440 \\
\hline water trap & standard & pieces & 220 \\
\hline gate valve & standard & pieces & 300 \\
\hline primer coat & metallic antisaline & 4 liters & 500 \\
\hline Bituminous paint & red and black & 4 liters & 500 \\
\hline
\end{tabular}

The sequence and times for constructing the digester pit were proposed as follows:

1. Building the concrete base - approximately one day.

2. Laying the stones and applying mortar $-1.5 \mathrm{~m}$ per day

3. Plastering the walls - approximately one day.

The labor rates in force are:

- Excavation - Kshs $200 / \mathrm{m}^{3}$

- Hiring a mason - Kshs 300/day

- Hiring an assistant mason - Kshs 150/day

One mason and an assistant mason can build approximately $12 \mathrm{~m}^{2}$ of a wall in a day. Thus depending on the size of the digester and hence the surface area of the digester pit, it may be necessary to hire one mason and several assistant masons. Table VIII shows the material requirement and cost for building digester pits, as well as influent and effluent tanks.

TABLE VIII

MATERIALS LIST AND THEIR RESPECTIVE COSTS (OBTAINED FROM TUMAINE HARDWARE, P.O. BOX 288, KALIMONI, KENYA) FOR CONSTRUCTION OF DIGESTER PITS

\begin{tabular}{|c|c|c|c|c|c|c|c|c|c|c|c|}
\hline $\begin{array}{l}\text { Cows } \\
\text { (No.) }\end{array}$ & $\begin{array}{c}\text { Persons } \\
\text { (No.) }\end{array}$ & $\begin{array}{l}\text { Stones } \\
\text { (No.) }\end{array}$ & $\begin{array}{l}\text { Cost of } \\
\text { Stones } \\
\text { (Kshs) }\end{array}$ & $\begin{array}{c}\begin{array}{c}\text { Bags of } \\
\text { cement }\end{array} \\
\text { (No.) }\end{array}$ & $\begin{array}{l}\text { Cost of } \\
\text { cement } \\
\text { (Kshs) }\end{array}$ & $\begin{array}{c}\text { Quantity } \\
\text { of sand } \\
\text { (tons) }\end{array}$ & $\begin{array}{c}\text { Cost of } \\
\text { sand } \\
\text { (Kshs) }\end{array}$ & $\begin{array}{c}\text { Quantity } \\
\text { of ballast } \\
\text { (tons) }\end{array}$ & $\begin{array}{c}\begin{array}{c}\text { Cost of } \\
\text { ballast }\end{array} \\
\text { (Kshs) }\end{array}$ & $\begin{array}{l}\text { Cost of } \\
\text { labour } \\
\text { (Kshs) }\end{array}$ & $\begin{array}{l}\text { Overall } \\
\text { total cost } \\
\text { (Kshs) }\end{array}$ \\
\hline 1 & 1 & 76 & 1976 & 7 & 3255 & 0.8 & 960 & 1.3 & 1872 & 1600 & 11983 \\
\hline 3 & 5 & 176 & 4576 & 11 & 5115 & 1.3 & 1560 & 1.9 & 2736 & 1990 & 19647 \\
\hline 6 & 10 & 265 & 6890 & 13 & 6045 & 1.7 & 2040 & 2.3 & 3312 & 3080 & 25937 \\
\hline 8 & 15 & 334 & 8684 & 15 & 6975 & 1.9 & 2280 & 2.6 & 3744 & 3570 & 30423 \\
\hline 11 & 20 & 391 & 10166 & 16 & 7440 & 2.3 & 2520 & 2.7 & 3888 & 4060 & 33694 \\
\hline 14 & 25 & 453 & 11778 & 17 & 7905 & 2.4 & 2880 & 2.9 & 4176 & 4550 & 37359 \\
\hline 17 & 30 & 511 & 13286 & 19 & 8835 & 2.5 & 3000 & 3 & 4320 & 4940 & 40926 \\
\hline
\end{tabular}

\section{Cost of the Gas Holder Materials and Labor}

Plain mild steel sheets of gauge 14 (3mm thick) were recommended for the fabrication of gas holders since they are easy to cut and form. These mild steel sheets are available in standard sizes of $(2.44 \mathrm{~m} \times 1.22 \mathrm{~m})$. The labor cost for hiring an artisan, welding equipment and electricity is normally taken as $0.2 \times$ materials cost (courtesy of Welding workshop, JKUAT). Welding one mild steel sheet will require approximately one packet of welding rods. One tin $(4 \mathrm{~L})$ of paint will paint a surface area of approximately $3 \mathrm{~m}^{2}$. Table IX below shows the total cost of fabricating a gas holder ${ }^{244}$. 
TABLE IX

MATERIAL REQUIREMENT AND THEIR RESPECTIVE COSTS (OBTAINED FROM TUMAINE HARDWARE, P.O. BOX 288, KALIMONI, KENYA) FOR FABRICATING THE GAS HOLDER.

\begin{tabular}{cccccccccc}
\hline Cows & Persons & Sheets & $\begin{array}{c}\text { Cost of } \\
\text { sheets }\end{array}$ & $\begin{array}{c}\text { Cost of welding } \\
\text { rods }\end{array}$ & $\begin{array}{c}\text { Cost of GI } \\
\text { pipe }\end{array}$ & $\begin{array}{c}\text { Cost of } \\
\text { paint }\end{array}$ & $\begin{array}{c}\text { Cost of } \\
\text { labor }\end{array}$ & $\begin{array}{c}\text { Overall total } \\
\text { cost }\end{array}$ \\
$\left(\begin{array}{c}\text { No. }) \\
1\end{array}\right.$ & (No.) & $($ No. $)$ & $($ kshs $)$ & $(\mathrm{kshs})$ & $(\mathrm{kshs})$ & $(\mathrm{kshs})$ & $(\mathrm{kshs})$ & $(\mathrm{kshs})$ \\
3 & 1 & 2 & 3180 & 340 & 685 & 1500 & 1141 & 6846 \\
6 & 5 & 4 & 6360 & 510 & 913 & 1500 & 1856 & 11140 \\
8 & 10 & 5 & 7950 & 680 & 1063 & 1500 & 2237 & 13432 \\
11 & 15 & 5 & 7950 & 850 & 1165 & 1500 & 2293 & 13758 \\
14 & 20 & 6 & 9540 & 1020 & 1262 & 1500 & 2662 & 15974 \\
17 & 25 & 7 & 11130 & 1190 & 1323 & 1500 & 3029 & 18172 \\
\hline
\end{tabular}

\section{AUXILIARY PARTS}

The central guide mechanism.

As the volume of gas that is generated increases it pushes the gas holder upwards which later retracts back into the digester pit as the gas is used up. This up and down movement of the gas holder requires a central guide mechanism to prevent the gas drum from jamming onto the sides of the digester. The central guide mechanism consists of a mild steel rod of $30 \mathrm{~mm}$ coated with 1 layer of primer and 2 layers of oil paint onto which is applied a layer of grease to lubricate the system and also to protect the rod against corrosion.

\section{Water trap}

When the gas collected flows along the gas outlet pipe, some water condenses along the pipe necessitating the use of a water trap. Standard water traps are available and should be installed along the gas pipe and just before the consumer point. Water traps encourage condensation, subsequent retention and eventual discharge of water in the biogas.

\section{Gate valve}

A gate valve is required at the outlet of the gas drum to regulate the flow of the gas depending on the consumer requirements.

Slurry influent and effluent pipes 
Standard pipes of polyvinyl chloride (PVC) should be used for slurry flowing into and out of the digester. PVC is recommended since it does not corrode in the alkaline conditions prevailing in the digester and is therefore more durable than galvanized iron pipes.

Material requirements and their respective cost (Obtained from Tumaine Hardware, P.O. Box 288, Kalimoni, Kenya) for the accessories discussed above are tabulated in Table X below.

\section{TABLE X}

MATERIAL REQUIREMENTS AND THE RESPECTIVE COSTS FOR THE ACCESSORIES

\begin{tabular}{ccccccccc}
\hline Cows & Persons & \multicolumn{2}{c}{ Central guide rod } & \multicolumn{2}{c}{ Inlet/outlet pipe } & Gate valve & $\begin{array}{c}\text { Water trap } \\
\text { Overall } \\
\text { total }\end{array}$ \\
\hline (No.) & $($ No. $)$ & $\begin{array}{c}\text { Length } \\
(\mathrm{m})\end{array}$ & $\begin{array}{c}\text { Cost } \\
(\text { Kshs })\end{array}$ & $\begin{array}{c}\text { Length } \\
(\mathrm{m})\end{array}$ & $\begin{array}{c}\text { Cost } \\
(\text { Kshs })\end{array}$ & $\begin{array}{c}\text { Cost } \\
(\text { Kshs })\end{array}$ & $\begin{array}{c}\text { Cost } \\
(\text { Kshs })\end{array}$ & $\begin{array}{c}\text { Cost } \\
\text { (Kshs })\end{array}$ \\
\hline 1 & 1 & 1.15 & 1800 & 4 & 1230 & 300 & 220 & 3550 \\
3 & 5 & 1.76 & 3150 & 5 & 1533 & 300 & 220 & 4903 \\
6 & 10 & 2.14 & 4050 & 6 & 1850 & 300 & 220 & 6420 \\
8 & 15 & 2.41 & 4650 & 8 & 2467 & 300 & 220 & 7637 \\
11 & 20 & 2.62 & 5100 & 9 & 2775 & 300 & 220 & 8395 \\
14 & 25 & 2.8 & 5550 & 10 & 3083 & 300 & 220 & 9953 \\
17 & 30 & 2.96 & 5925 & 12 & 3700 & 300 & 220 & 10145 \\
\hline
\end{tabular}

Table XI below shows the total cost of installing biogas units of different sizes depending on the number of cows and therefore cow dung available. Since the costs given in this paper relate to the Kenyan market, the cost information provided can only act as a guide for external markets. Conversions of the Kenya shilling to some of the major international currencies in Kenya as on the $15^{\text {th }}$ of January 2008 were; Kshs 68 to one US Dollar, Kshs 133 to one Sterling Pound, Kshs 101 to one Euro and Kshs 0.62 to one Japanese Yen.

TABLE XI

TOTAL COST OF A BIOGAS PLANT

\begin{tabular}{|c|c|c|c|c|c|}
\hline $\begin{array}{l}\text { Cows } \\
\text { (No.) } \\
\end{array}$ & $\begin{array}{l}\text { Persons } \\
\text { (No.) } \\
\end{array}$ & $\begin{array}{c}\text { Cost of digester } \\
\text { (Kshs) }\end{array}$ & $\begin{array}{c}\text { Cost of gas } \\
\text { holder } \\
\text { (Kshs.) }\end{array}$ & $\begin{array}{c}\text { Cost of } \\
\text { accessories } \\
\text { (Kshs) }\end{array}$ & $\begin{array}{c}\text { Overall total cost } \\
\text { (Kshs) }\end{array}$ \\
\hline 1 & 1 & 11983 & 6486 & 3550 & 20,059 \\
\hline 3 & 5 & 19647 & 11140 & 4903 & 32,320 \\
\hline 6 & 10 & 25937 & 13423 & 6420 & 41,219 \\
\hline 8 & 15 & 30423 & 13758 & 7637 & 46,648 \\
\hline 11 & 20 & 33694 & 15974 & 8395 & 52,443 \\
\hline 14 & 25 & 37359 & 18172 & 9953 & 58,614 \\
\hline 17 & 30 & 40926 & 20359 & 10145 & 64,985 \\
\hline
\end{tabular}


This report provides literature on the necessary requirements for installing a biogas unit. It presents information on how to develop a bill of quantities and complete costing of various size biogas units, based on available cow dung slurry (number of cows), for the floating drum biogas plant and includes an example of the sizing and costing of a digester in Kenya.

\section{RECOMMENDATIONS}

- Standard designs for the piping network from the digester to the consumer should be developed for uses on institutional biogas units.

- A computer program should be developed to assist in determining the bill of quantities and costing of various size biogas units based on the available cow dung (number of cows).

- A means of sustaining thermophilic temperatures should be developed, as productivity of biogas is higher in this temperature region.

- Design for an integrated biogas system that includes scrubbing, charging and storage systems should be developed.

- Charging mechanisms, pressure regulators and flame arrestors should be developed and standardized for easy uptake by users.

\section{REFERENCES}

${ }^{1}$ G. Oelert, F. Aner and K. Pertz, "Economic Issues of Renewable Energy Systems", published by GTZ, 1987.

2 Joint Donor Statement for the Kenya Consultative Group Meeting, Energy Sector, 2003.

3 "Kenya Deforestation Rates and Related Forestry Figures", Global Forest Assessment and the State of the World's Forests, 2005.

4 "Water: A Shared Responsibility - Kenya", World Water Assessment Program by AFDEC, 2006.

5 "Water: A Shared Responsibility - Kenya", 2006.

${ }^{6}$ Kenya Electricity Generating Company Limited Prospectus, 2006.

${ }^{7}$ Joint Donor Statement for the Kenya Consultative Group Meeting, Energy Sector, 2003.

${ }^{8}$ Perssson M., Jönsson O. and Wellinger A., "Biogas Scrubbing to Vehicle Fuel Standards and Grid Injection, IEA, BioEnergy, 2006, http://www.iea-biogas.net/Dokumente/upgrading report final.pdf, accessed on the $24^{\text {th }}$ of May 2007..

${ }^{9}$ Perssson M., Jönsson O. and Wellinger A., "Biogas Scrubbing to Vehicle Fuel Standards and Grid Injection, IEA, BioEnergy, 2006.

${ }^{10}$ David Fulford, "Running a Biogas Programme", Immediate Technology Publications, 1988.

${ }^{11}$ David Fulford, "Running a Biogas Programme", 1988.

12 "Dissemination of Biogas Plants In Rural Areas of Kenya", Published by Special Energy Programme (SEP), Kenya, 1987.

13 "Dissemination of Biogas Plants In Rural Areas of Kenya", 1987.

14 "Dissemination of Biogas Plants In Rural Areas of Kenya", 1987.

${ }^{15}$ Steven Mckinsey Zicari, "Removal of Hydrogen Sulfide from Biogas Using Cow-manure Compost", MSc Thesis, Graduate School of Cornell University, 2003.

${ }^{16}$ Fowler S., "A System Approach to Biogas Technology", SD: Environment, http://www.habmigern2003.info/biogas/methane-digester.html, accessed on the $24^{\text {th }}$ of May 2007.

${ }_{17}$ Waste Digester Design, http://www.ce.ufl.edu/activities/waste/wddstu.html, accessed on the $24^{\text {th }}$ of May 2007.

${ }^{18}$ David Fulford, "Running a Biogas Programme", 1988.

19 "Bioconversion of organic residues for rutal communities", Division of Scientific Research and Higher Education, UNESCO, Paris, France, 
http://www.unu.edu/unupress/unupbooks/80434e/80434E0j.htm\#Introduction, accessed on the $24^{\text {th }}$ of May 2007

20 "Bioconversion of organic residues for rutal communities", accessed on the $24^{\text {th }}$ of May 2007

21 "A Systems Approach to Biogas Technology", from "Biogas technology: a training manual for extension" (FAO/CMS, 1996), Sustainable Development Department (SD), Food and Agricultural Organization of the United Nations (FAO), SD: Environment: Energy and Environmental Technology, June 1997, http://www.fao.org/sd/EGdirect/EGre0022.htm, accessed on the $24^{\text {th }}$ of May 2007

${ }^{22}$ Waste Digester Design, accessed on the $24^{\text {th }}$ of May 2007.

23 “A Systems Approach to Biogas Technology”, June 1997.

24 “A Systems Approach to Biogas Technology”, June 1997.

25 “A Systems Approach to Biogas Technology", June 1997.

${ }^{26}$ Waste Digester Design, accessed on the $24^{\text {th }}$ of May 2007.

${ }^{27}$ Zhiyou W. and Shulin C., "Development of a sequential continuous stirred tank reactor (CSTR) system for anaerobic digestion of liquid dairy manure", 2006 ASABE Annual International Meeting Sponsored by ASABE Oregon Convention Center Portland, Oregon 9 - 12 July 2006, Paper Number: 067070.

${ }^{28}$ Shannon R., "Biogas", Sixth International Permaculture Conference \& Convergence: Designing for a sustainable future, Perth \& Bridgetown, Western Australia, September 27 to October 7, 1996, http://www.rosneath.com.au/ipc6/ch08/shannon2/index.html, accessed on the $24^{\text {th }}$ of May 2007.

${ }^{29}$ Shannon R., "Biogas", September 27 to October 7, 1996, http://www.rosneath.com.au/ipc6/ch08/shannon2/index.html, accessed on the $24^{\text {th }}$ of May 2007.

${ }^{30}$ Wheeler P., Jaatinen T., Lindberg A., Lundeberg S., Holm-Nielsen J. B., Arthur Wellinger A. and Pettigrew A., "Biogas Upgrading and Utilisation", IEA Bioenergy, Task 24 Energy from Biological Conversion of Organic Waste, http://www.recyclenow.org/Report IEA_Bioenergy_1MB.pdf - accessed on the $24^{\text {th }}$ of May 2007.

${ }^{31}$ Shannon R., "Biogas", September 27 to October 7, 1996,

${ }^{32}$ Moser M. A., “A Dozen Successful Swine Waste Digesters”, RCM Digesters, Inc., Â@ Copyright 2006 RCM Digesters, all rights reserved, http://www.rcmdigesters.com/, accessed on the $26^{\text {th }}$ of June 2007.

http://www.egr.msu.edu/ safferma/Research/Greeen/intermediateresults/Draft $\% 20$ Anaerobic $\% 20$ Literature $\% 20$ Review\%20-\%20December\%2022\%202006.pdf, accessed on the $26^{\text {th }}$ of June 2007.

33 "Methane Generation from Human, Animal and Agricultural Wastes", National Academy of Sciences, Washington, D. C. 1977.

34 “Energy for Rural Development, Renewable Resources and Alterative Technologies for Developing Countries", Supplement, National Academy Press, Washington D. C. 1981.

${ }^{35}$ Maina Maringa, Notes on Biogas generation and sizing of Biogas units, Jomo Kenyatta University of Agriculture and Technology, 1996.

${ }^{36}$ Sugiyama M., Okazaki T. and Kondo T., "Gas storage method and system, and gas occluding material", Toyota Jidosha Kabushiki Kaisha, C 2004-6 PatentStorm LLC. All rights reserved, US Patent Issued on November 19, 2002, http://www.patentstorm.us/patents/6481217-fulltext.html, accessed on the $23^{\text {rd }}$ of May 2007.

${ }^{37}$ Khokhar A. A., Sloan E. D. And Gudmundsson J. S., "Natural Gas Storage Properties of Structure H Hydrate", Annals of the New York Academy of Sciences, Volume 912, January 200, Gas Hydrates: Challenges for the Future: 950-957, January 2000.

${ }^{38}$ Khokhar A. A., Sloan E. D. And Gudmundsson J. S., "Natural Gas Storage Properties of Structure H Hydrate", Volume 912, January 2000.

${ }^{39}$ Khokhar A. A., Sloan E. D. And Gudmundsson J. S., "Natural Gas Storage Properties of Structure H Hydrate", Volume 912, January 2000.

40 "Methane", http://www.renewablesnorthwest.co.uk/renewables/gas.htm, accessed on the $23^{\text {rd }}$ of May 2007.

${ }^{41}$ Wheeler P., Jaatinen T., Lindberg A., Lundeberg S., Holm-Nielsen J. B., Arthur Wellinger A. and Pettigrew A., "Biogas Upgrading and Utilisation", IEA Bioenergy, Task 24 Energy from Biological Conversion of Organic Waste, http://www.recyclenow.org/Report IEA Bioenergy 1MB.pdf, accessed on the $24^{\text {th }}$ of May 2007.

${ }^{42}$ Perssson M., Jönsson O. and Wellinger A., "Biogas Scrubbing to Vehicle Fuel Standards and Grid Injection, IEA, BioEnergy, 2006, http://www.iea-biogas.net/Dokumente/upgrading report final.pdf, accessed on the $24^{\text {th }}$ of May 2007.

${ }^{43}$ Wheeler P., Jaatinen T., Lindberg A., Lundeberg S., Holm-Nielsen J. B., Arthur Wellinger A. and Pettigrew A., "Biogas Upgrading and Utilisation", accessed on the $24^{\text {th }}$ of May 2007.

${ }^{44}$ Perssson M., Jönsson O. and Wellinger A., "Biogas Scrubbing to Vehicle Fuel Standards and Grid Injection, 
IEA, BioEnergy, 2006.

45 “Biogasification", Solid Waste Management, Volume 1 Chapter X1, United Nations Environment Programme Division of Technology, Industry, and Economics, http://www.unep.or.jp/Ietc/Publications/spc/Solid Waste_Management/Vol I/17-Chapter11.pdf, accessed on the $24^{\text {th }}$ of May 2007.

${ }^{46}$ Shannon R., "Biogas", September 27 to October 7, 1996.

${ }^{47}$ Steven Mckinsey Zicari, "Removal of Hydrogen Sulfide from Biogas Using Cow-manure Compost", 2003.

48 "Biogas Utilization Handbook", Published by the Environment, Safety and Health Divison, Georgia Tech Research Institute, Atlanta Georgia, http://www.p2pays.org/ref/22/21262.pdf, accessed on the $24^{\text {th }}$ of May 2007.

49 "Biogasification", accessed on the $24^{\text {th }}$ of May 2007.

${ }^{50}$ Fowler S., "A System Approach to Biogas Technology”, accessed on the $24^{\text {th }}$ of May 2007.

51 "Biogasification", accessed on the $24^{\text {th }}$ of May 2007.

${ }^{52}$ Perssson M., Jönsson O. and Wellinger A., "Biogas Scrubbing to Vehicle Fuel Standards and Grid Injection, IEA, BioEnergy, 2006.

${ }^{53}$ J. Hohfeld and L. Sasse, "Production and Utilization of Biogas in Rural Areas of Industrialized and Developing Countries", Published by GTZ, 1985.

${ }^{54}$ Shannon R., "Biogas", September 27 to October 7, 1996.

55 "Biogas Utilization Handbook", accessed on the $24^{\text {th }}$ of May 2007.

${ }^{56}$ Shannon R., "Biogas", September 27 to October 7, 1996.

57 "Biogas Utilization Handbook", accessed on the $24^{\text {th }}$ of May 2007.

58 "Biogas Utilization Handbook", accessed on the $24^{\text {th }}$ of May 2007.

${ }^{59}$ Shannon R., "Biogas", September 27 to October 7, 1996.

60 "Biogas Utilization Handbook", accessed on the $24^{\text {th }}$ of May 2007.

61 "Integrated Pollution Prevention and Control", Draft Document on Best Available Techniques for the Wastes Treatment Industry, European Commission Directorate-General Joint Research Centre (JRC), Institute for Prospective Technological Studies (Seville), Technologies for Sustainable Development, European IPPC Bureau, Draft, February 2003, http://www.defra.gov.uk/environment/ppc/envagency/pubs/pdf/ippcguide ed4.pdf, accessed on the $24^{\text {th }}$ of May 2007.

62 "Biogas Utilization Handbook", accessed on the $24^{\text {th }}$ of May 2007.

${ }^{63}$ Handerson E., "Anaerobic Treatability of Methane Production From fruit and Vegetable Process Waste", Green Project Alternatives for Food Processor's WasteWater, Michigan State University, Steven Safferman, December 2006 Draft,

http://www.egr.msu.edu/ safferma/Research/Greeen/intermediateresults/Draft $\% 20$ Anaerobic $\% 20$ Literature $\% 20$ Review\%20-\%20December\%2022\%202006.pdf, accessed on the $26^{\text {th }}$ of June 2007.

${ }^{64}$ DGS Series- Biogas Scrubber for Hydrogen Sulphide, CAT. \#05-003-U \#08-028, Apollo Environmental Systems Ltd., Toronto, Ontario, Canada, www.apollo-environmental.com, accessed on the $23^{\text {rd }}$ of May 2007.

65 "Integrated Pollution Prevention and Control", February 2003.

${ }^{66}$ Wheeler P., Jaatinen T., Lindberg A., Lundeberg S., Holm-Nielsen J. B., Arthur Wellinger A. and Pettigrew A., "Biogas Upgrading and Utilisation", accessed on the $24^{\text {th }}$ of May 2007.

67 "Biogas Utilization Handbook", accessed on the $24^{\text {th }}$ of May 2007.

${ }^{68}$ Syed M., Soreanu G., Falletta P. and Béland M., "Removal of Hydrogen Sulfide from gas Streams Using Biological Processes -A Review", Canadian Biosystems Engineering, pp. 2.1 - 1.14, Volume 48, 2006.

${ }^{69}$ Syed M., Soreanu G., Falletta P. and Béland M., "Removal of Hydrogen Sulfide from gas Streams Using Biological Processes -A Review”, 2006.

${ }^{70}$ Wheeler P., Jaatinen T., Lindberg A., Lundeberg S., Holm-Nielsen J. B., Arthur Wellinger A. and Pettigrew A., "Biogas Upgrading and Utilisation", accessed on the $24^{\text {th }}$ of May 2007.

${ }^{71}$ J. Hohfeld and L. Sasse, "Production and Utilization of Biogas in Rural Areas of Industrialized and Developing Countries", 1985.

${ }^{72}$ Shannon R., "Biogas”, September 27 to October 7, 1996.

${ }^{73}$ Tomadakis M. M. and Heck H. H, "Utilization of Landfill gas Towards High-BTU Methane and Low-Cost Hydrogen Fuel Production", Florida Institute of Technology, Florida Centre for Solid and Hazardous Waste Management, University of Florida, Report \# 0332005-04, October 2004, http://www.hinkleycenter.com/publications/freport tomadakis.pdf, accessed on the $26^{\text {th }}$ of June 2007.

${ }^{74}$ Kapdi S. S., Vijay* V .K., Rajesh S. K. and Prasad R., "Biogas Scrubbing, Compression and Storage: Perspective and Prospectus in Indian Context”, Renewable Energy, Volume 30, Issue 8, July 2005, Pages 1195-1202. 
75 "Biogas Utilization Handbook", accessed on the $24^{\text {th }}$ of May 2007.

${ }^{76}$ Wheeler P., Jaatinen T., Lindberg A., Lundeberg S., Holm-Nielsen J. B., Arthur Wellinger A. and Pettigrew A., "Biogas Upgrading and Utilisation", accessed on the $24^{\text {th }}$ of May 2007.

${ }^{77}$ Wheeler P., Jaatinen T., Lindberg A., Lundeberg S., Holm-Nielsen J. B., Arthur Wellinger A. and Pettigrew A., "Biogas Upgrading and Utilisation", accessed on the $24^{\text {th }}$ of May 2007.

${ }^{78}$ Glancy, D. L., College, J. W. and Wilhelm, J. S., "Sodium-enhanced lime scrubbing method for removing sulfur dioxide from gaseous streams", United States Patent 5266285 , http://www.freepatentsonline.com/5266285.html, accessed on the $11^{\text {th }}$ of June 2007.

${ }^{79}$ Tomadakis M. M. and Heck H. H, "Utilization of Landfill gas Towards High-BTU Methane and Low-Cost Hydrogen Fuel Production", October 2004.

${ }^{80}$ Kapdi S. S., Vijay* V .K., Rajesh S. K. and Prasad R., "Biogas Scrubbing, Compression and Storage: Perspective and Prospectus in Indian Context", July 2005.

${ }^{81}$ Syed M., Soreanu G., Falletta P. and Béland M., "Removal of Hydrogen Sulfide from gas Streams Using Biological Processes -A Review", 2006.

${ }^{82}$ Wheeler P., Jaatinen T., Lindberg A., Lundeberg S., Holm-Nielsen J. B., Arthur Wellinger A. and Pettigrew A., "Biogas Upgrading and Utilisation", accessed on the $24^{\text {th }}$ of May 2007.

${ }^{83}$ Wheeler P., Jaatinen T., Lindberg A., Lundeberg S., Holm-Nielsen J. B., Arthur Wellinger A. and Pettigrew A., "Biogas Upgrading and Utilisation", accessed on the $24^{\text {th }}$ of May 2007.

${ }^{84}$ Perssson M., Jönsson O. and Wellinger A., "Biogas Scrubbing to Vehicle Fuel Standards and Grid Injection, IEA, BioEnergy, 2006.

${ }^{85}$ Buisman C. J. N., "Process for the removal of sulphur compounds from gases", US Patent Issued on October 11, 1994, http://www.patentstorm.us/patents/5354545-fulltext.html, accessed on the $16^{\text {th }}$ of June 2007.

${ }^{86}$ Kapdi S. S., Vijay* V .K., Rajesh S. K. and Prasad R., "Biogas Scrubbing, Compression and Storage: Perspective and Prospectus in Indian Context", July 2005.

${ }^{87}$ Syed M., Soreanu G., Falletta P. and Béland M., "Removal of Hydrogen Sulfide from gas Streams Using Biological Processes -A Review”, 2006.

${ }^{88}$ Maina Maringa, Notes on Biogas generation and sizing of Biogas units, Jomo Kenyatta University of Agriculture and Technology, 1996.

${ }^{89}$ Wheeler P., Jaatinen T., Lindberg A., Lundeberg S., Holm-Nielsen J. B., Arthur Wellinger A. and Pettigrew A., "Biogas Upgrading and Utilisation", accessed on the $24^{\text {th }}$ of May 2007.

${ }^{90}$ Maina Maringa, Notes on Biogas generation and sizing of Biogas units, 1996.

${ }^{91}$ Shannon R., "Biogas”, September 27 to October 7, 1996.

${ }^{92}$ Wheeler P., Jaatinen T., Lindberg A., Lundeberg S., Holm-Nielsen J. B., Arthur Wellinger A. and Pettigrew A., "Biogas Upgrading and Utilisation", accessed on the $24^{\text {th }}$ of May 2007.

${ }^{93}$ Perssson M., Jönsson O. and Wellinger A., "Biogas Scrubbing to Vehicle Fuel Standards and Grid Injection, IEA, BioEnergy, 2006.

${ }^{94}$ Wheeler P., Jaatinen T., Lindberg A., Lundeberg S., Holm-Nielsen J. B., Arthur Wellinger A. and Pettigrew A., "Biogas Upgrading and Utilisation", accessed on the $24^{\text {th }}$ of May 2007.

${ }^{95}$ Wheeler P., Jaatinen T., Lindberg A., Lundeberg S., Holm-Nielsen J. B., Arthur Wellinger A. and Pettigrew A., "Biogas Upgrading and Utilisation", accessed on the $24^{\text {th }}$ of May 2007.

${ }^{96}$ Perssson M., Jönsson O. and Wellinger A., "Biogas Scrubbing to Vehicle Fuel Standards and Grid Injection, IEA, BioEnergy, 2006.

${ }^{97}$ Kapdi S. S., Vijay* V .K., Rajesh S. K. and Prasad R., "Biogas Scrubbing, Compression and Storage: Perspective and Prospectus in Indian Context", July 2005.

${ }^{98}$ Maina Maringa, Notes on Biogas generation and sizing of Biogas units, 1996.

${ }^{99}$ Shannon R., "Biogas", September 27 to October 7, 1996.

${ }^{100}$ Kapdi S. S., Vijay* V .K., Rajesh S. K. and Prasad R., "Biogas Scrubbing, Compression and Storage: Perspective and Prospectus in Indian Context", July 2005.

${ }^{101}$ Kuria K. J., "Extending the Existing Solutions for Domestic Production of Biogas for a Single Homestead to Institutional Provisions", BSc Research Project Report, Jomo Kenyatta University of Agriculture and Technology, 2004.

102 Kapdi S. S., Vijay* V .K., Rajesh S. K. and Prasad R., "Biogas Scrubbing, Compression and Storage: Perspective and Prospectus in Indian Context", July 2005.

${ }^{103}$ Kapdi S. S., Vijay* V .K., Rajesh S. K. and Prasad R., "Biogas Scrubbing, Compression and Storage: Perspective and Prospectus in Indian Context", July 2005.

${ }^{104}$ Wheeler P., Jaatinen T., Lindberg A., Lundeberg S., Holm-Nielsen J. B., Arthur Wellinger A. and Pettigrew A., "Biogas Upgrading and Utilisation", accessed on the $24^{\text {th }}$ of May 2007.

${ }^{105}$ Kapdi S. S., Vijay* V .K., Rajesh S. K. and Prasad R., "Biogas Scrubbing, Compression and Storage: 
Perspective and Prospectus in Indian Context”, July 2005.

${ }^{106}$ Steven Mckinsey Zicari, "Removal of Hydrogen Sulfide from Biogas Using Cow-manure Compost", 2003.

107 Shannon R., "Biogas", September 27 to October 7, 1996.

${ }^{108}$ Kapdi S. S., Vijay* V .K., Rajesh S. K. and Prasad R., "Biogas Scrubbing, Compression and Storage:

Perspective and Prospectus in Indian Context", July 2005.

109 "Biogas Utilization Handbook", accessed on the $24^{\text {th }}$ of May 2007.

${ }^{110}$ Steven Mckinsey Zicari, "Removal of Hydrogen Sulfide from Biogas Using Cow-manure Compost", 2003.

111 "Biogas Utilization Handbook", accessed on the $24^{\text {th }}$ of May 2007.

${ }^{112}$ Kapdi S. S., Vijay* V .K., Rajesh S. K. and Prasad R., "Biogas Scrubbing, Compression and Storage: Perspective and Prospectus in Indian Context", July 2005.

${ }^{113}$ Wheeler P., Jaatinen T., Lindberg A., Lundeberg S., Holm-Nielsen J. B., Arthur Wellinger A. and Pettigrew A., "Biogas Upgrading and Utilisation", accessed on the $24^{\text {th }}$ of May 2007.

114 Shannon R., "Biogas", September 27 to October 7, 1996.

115 "Biogas Utilization Handbook", accessed on the $24^{\text {th }}$ of May 2007.

${ }^{116}$ J. Hohfeld and L. Sasse, "Production and Utilization of Biogas in Rural Areas of Industrialized and Developing Countries", 1985.

${ }^{117}$ Steven Mckinsey Zicari, "Removal of Hydrogen Sulfide from Biogas Using Cow-manure Compost", 2003.

118 Steven Mckinsey Zicari, "Removal of Hydrogen Sulfide from Biogas Using Cow-manure Compost", 2003.

119 "Integrated Pollution Prevention and Control”, February 2003.

${ }^{120}$ Fowler S., "A System Approach to Biogas Technology", accessed on the $24^{\text {th }}$ of May 2007.

${ }^{121}$ Shannon R., "Biogas", September 27 to October 7, 1996.

${ }^{122}$ Hansen C., "Biogas Scrubbing System (Eliminating Corrosive Hydrogen Sulfide Gas)", The Local Energy Farms Network - Reliable Renewable Energy for a Post Carbon World, Post Carbon Institute, $10^{\text {th }}$ October 2006, http://www.energyfarms.net/node/1034, accessed on the $24^{\text {th }}$ of May 2007.

123 "Biogas Utilization Handbook", accessed on the $24^{\text {th }}$ of May 2007.

${ }^{124}$ Wheeler P., Jaatinen T., Lindberg A., Lundeberg S., Holm-Nielsen J. B., Arthur Wellinger A. and Pettigrew A., "Biogas Upgrading and Utilisation", accessed on the $24^{\text {th }}$ of May 2007.

${ }^{125}$ Steven Mckinsey Zicari, "Removal of Hydrogen Sulfide from Biogas Using Cow-manure Compost", 2003.

${ }^{126}$ Wheeler P., Jaatinen T., Lindberg A., Lundeberg S., Holm-Nielsen J. B., Arthur Wellinger A. and Pettigrew A., "Biogas Upgrading and Utilisation", accessed on the $24^{\text {th }}$ of May 2007.

127 "Biogasification", accessed on the $24^{\text {th }}$ of May 2007.

${ }^{128}$ Kapdi S. S., Vijay* V .K., Rajesh S. K. and Prasad R., "Biogas Scrubbing, Compression and Storage: Perspective and Prospectus in Indian Context", July 2005.

129 "Biogas Utilization Handbook", accessed on the $24^{\text {th }}$ of May 2007.

${ }^{130}$ Maina Maringa, Notes on Biogas generation and sizing of Biogas units, 1996.

${ }^{131}$ Steven Mckinsey Zicari, "Removal of Hydrogen Sulfide from Biogas Using Cow-manure Compost", 2003.

132 Steven Mckinsey Zicari, "Removal of Hydrogen Sulfide from Biogas Using Cow-manure Compost”, 2003.

${ }^{133}$ Maina Maringa, Notes on Biogas generation and sizing of Biogas units, 1996.

${ }^{134}$ J. Hohfeld and L. Sasse, "Production and Utilization of Biogas in Rural Areas of Industrialized and Developing Countries", 1985.

${ }^{135}$ Steven Mckinsey Zicari, "Removal of Hydrogen Sulfide from Biogas Using Cow-manure Compost”, 2003.

${ }^{136}$ Kuria K. J., "Extending the Existing Solutions for Domestic Production of Biogas for a Single Homestead to Institutional Provisions", 2004.

${ }^{137}$ Shannon R., "Biogas", September 27 to October 7, 1996.

${ }^{138}$ Steven Mckinsey Zicari, "Removal of Hydrogen Sulfide from Biogas Using Cow-manure Compost", 2003.

139 "Biogas Utilization Handbook", accessed on the $24^{\text {th }}$ of May 2007.

${ }^{140}$ Steven Mckinsey Zicari, "Removal of Hydrogen Sulfide from Biogas Using Cow-manure Compost”, 2003.

${ }^{141}$ Perssson M., Jönsson O. and Wellinger A., "Biogas Scrubbing to Vehicle Fuel Standards and Grid Injection, IEA, BioEnergy, 2006.

${ }^{142}$ Wheeler P., Jaatinen T., Lindberg A., Lundeberg S., Holm-Nielsen J. B., Arthur Wellinger A. and Pettigrew A., "Biogas Upgrading and Utilisation", accessed on the $24^{\text {th }}$ of May 2007.

${ }^{143}$ Wheeler P., Jaatinen T., Lindberg A., Lundeberg S., Holm-Nielsen J. B., Arthur Wellinger A. and Pettigrew A., "Biogas Upgrading and Utilisation", accessed on the $24^{\text {th }}$ of May 2007.

${ }^{144}$ Kapdi S. S., Vijay* V .K., Rajesh S. K. and Prasad R., "Biogas Scrubbing, Compression and Storage: Perspective and Prospectus in Indian Context", July 2005.

${ }^{145}$ Steven Mckinsey Zicari, "Removal of Hydrogen Sulfide from Biogas Using Cow-manure Compost", 2003.

${ }^{146}$ Wheeler P., Jaatinen T., Lindberg A., Lundeberg S., Holm-Nielsen J. B., Arthur Wellinger A. and Pettigrew A., "Biogas Upgrading and Utilisation", accessed on the $24^{\text {th }}$ of May 2007. 
147 "Energy for Rural Development, Renewable Resources and Alterative Technologies for Developing Countries", Supplement, National Academy Press, Washington D. C. 1981.

148 "Methane Generation from Human, Animal and Agricultural Wastes", National Academy of Sciences, Washington, D. C. 1977.

${ }^{149}$ David Fulford, "Running a Biogas Programme", 1988.

150 “A Systems Approach to Biogas Technology”, June 1997.

${ }^{151}$ F owler S., "A System Approach to Biogas Technology", accessed on the $24^{\text {th }}$ of May 2007.

152 "Bioconversion of organic residues for rutal communities", Division of Scientific Research and Higher Education, UNESCO, Paris, France, http://www.unu.edu/unupress/unupbooks/80434e/80434E0j.htm\#Introduction, accessed on the $24^{\text {th }}$ of May 2007.

153 "Energy for Rural Development, Renewable Resources and Alterative Technologies for Developing Countries", Supplement, National Academy Press, Washington D. C. 1981.

154 "Methane Generation from Human, Animal and Agricultural Wastes", National Academy of Sciences, Washington, D. C. 1977.

${ }^{155}$ Shannon R., "Biogas", September 27 to October 7, 1996.

${ }^{156}$ F owler S., "A System Approach to Biogas Technology", accessed on the $24^{\text {th }}$ of May 2007.

157 "Energy for Rural Development, Renewable Resources and Alterative Technologies for Developing Countries", Supplement, National Academy Press, Washington D. C. 1981.

158 "Methane Generation from Human, Animal and Agricultural Wastes", National Academy of Sciences, Washington, D. C. 1977.

${ }^{159}$ F owler S., "A System Approach to Biogas Technology”, accessed on the $24^{\text {th }}$ of May 2007.

${ }^{160}$ John Garcelon J. and Joe Clark J., "Waste Digester Design", http://www.ce.ufl.edu/activities/waste/wddins.html, accessed on the $22^{\text {nd }}$ of June 2007.

${ }_{161}$ Mähnert P., Heiermann M. and Linke B., "Batch- and Semi-continuous Biogas Production from Different Grass Species", Agricultural Engineering International Journal: the CIGR EJournal, Manuscript EE 05010. Vol. VII, December, 2005, http://cigr-ejournal.tamu.edu/volume7.html, accessed on the $26^{\text {th }}$ of June 2007.

${ }^{162}$ Shannon R., "Biogas", September 27 to October 7, 1996.

${ }^{163}$ Zhiyou W. and Shulin C., "Development of a sequential continuous stirred tank reactor (CSTR) system for anaerobic digestion of liquid dairy manure", 2006 ASABE Annual International Meeting Sponsored by ASABE Oregon Convention Center Portland, Oregon 9 - 12 July 2006, Paper Number: 067070.

${ }^{164}$ F owler S., "A System Approach to Biogas Technology", accessed on the $24^{\text {th }}$ of May 2007.

${ }^{165}$ F owler S., "A System Approach to Biogas Technology", accessed on the $24^{\text {th }}$ of May 2007.

${ }^{166}$ Barker J. C., "Fuel Gas from Livestock Wastes a Summary", North Carolina Cooperative Extension Service, Water Quality \& Waste Management, Publication Number: EBAE 071-80, March 14, 2001, http://www.bae.ncsu.edu/programs/extension/publicat/wqwm/ebae071 80.html, accessed on the $22^{\text {nd }}$ of June 2007.

${ }^{167}$ John Garcelon J. and Joe Clark J., "Waste Digester Design”, accessed on the $22^{\text {nd }}$ of June 2007.

${ }^{168}$ Barker J. C., "Fuel Gas from Livestock Wastes a Summary", March 14, 2001.

169 "A Systems Approach to Biogas Technology”, June 1997.

${ }^{170}$ F owler S., "A System Approach to Biogas Technology", accessed on the $24^{\text {th }}$ of May 2007.

${ }_{171}$ Waste Digester Design, accessed on the $24^{\text {th }}$ of May 2007.

172 "Methane Generation from Human, Animal and Agricultural Wastes", National Academy of Sciences, Washington, D. C. 1977.

173 “A Systems Approach to Biogas Technology”, June 1997.

174 “A Systems Approach to Biogas Technology”, June 1997.

175 Waste Digester Design, accessed on the $24^{\text {th }}$ of May 2007.

176 "Methane Generation from Human, Animal and Agricultural Wastes", National Academy of Sciences, Washington, D. C. 1977.

${ }^{177}$ Waste Digester Design, accessed on the $24^{\text {th }}$ of May 2007.

${ }^{178}$ John Garcelon J. and Joe Clark J., "Waste Digester Design", accessed on the $22^{\text {nd }}$ of June 2007.

179 "Methane Generation from Human, Animal and Agricultural Wastes", National Academy of Sciences, Washington, D. C. 1977.

180 “A Systems Approach to Biogas Technology”, June 1997.

181 "Methane Generation from Human, Animal and Agricultural Wastes", National Academy of Sciences, Washington, D. C. 1977.

182 "Bioconversion of organic residues for rutal communities", accessed on the $24^{\text {th }}$ of May 2007.

${ }^{183}$ John Garcelon J. and Joe Clark J., "Waste Digester Design”, accessed on the $22^{\text {nd }}$ of June 2007. 
${ }^{184}$ John Garcelon J. and Joe Clark J., "Waste Digester Design”, accessed on the $22^{\text {nd }}$ of June 2007.

${ }^{185}$ El-Halwagi, M. M., "Biogas Technology Transfer and Diffusion", Elsevier applied Science publishers, London, UK, 1984.

${ }^{186}$ David Fulford, "Running a Biogas Programme", 1988.

${ }^{187} \mathrm{~J}$. Hohfeld and L. Sasse, "Production and Utilization of Biogas in Rural Areas of Industrialized and Developing Countries", 1985.

${ }^{188}$ J. Hohfeld and L. Sasse, "Production and Utilization of Biogas in Rural Areas of Industrialized and Developing Countries", 1985.

${ }^{189}$ David Fulford, "Running a Biogas Programme”, 1988.

190 "Dissemination of Biogas Plants In Rural Areas of Kenya", 1987.

191 "Dissemination of Biogas Plants In Rural Areas of Kenya", 1987.

${ }^{192}$ Bhatia R.and Niamir M., "Renewable Energy Sources: The Community Biogas Plant|, Seminar at the Dept of Applied Sciences, Harvard University, USA, 1979.

${ }^{193}$ Barnett A., Pyle L. and Sabvamanian S. K., "Biogas technology in the Third World", International Developement Research Center, IDRC - 103e, 1978.

${ }^{194}$ J. Hohfeld and L. Sasse, "Production and Utilization of Biogas in Rural Areas of Industrialized and Developing Countries", 1985.

195 "A Systems Approach to Biogas Technology”, June 1997.

${ }^{196}$ F owler S., "A System Approach to Biogas Technology", accessed on the $24^{\text {th }}$ of May 2007.

${ }^{197}$ Shannon R., "Biogas", September 27 to October 7, 1996.

198 "Energy for Rural Development, Renewable Resources and Alterative Technologies for Developing Countries", 1981.

199 "Methane Generation from Human, Animal and Agricultural Wastes", 1977.

${ }^{200}$ J. Hohfeld and L. Sasse, "Production and Utilization of Biogas in Rural Areas of Industrialized and Developing Countries", 1985.

${ }^{201}$ Jenangi L., "Producing Methane from Effluent", Diploma Project, Adelaide University, 1999.

${ }^{202}$ F owler S., "A System Approach to Biogas Technology", accessed on the $24^{\text {th }}$ of May 2007.

${ }^{203}$ J. Hohfeld and L. Sasse, "Production and Utilization of Biogas in Rural Areas of Industrialized and Developing Countries", 1985.

${ }^{204}$ F owler S., "A System Approach to Biogas Technology", accessed on the $24^{\text {th }}$ of May 2007.

${ }^{205}$ J. Hohfeld and L. Sasse, "Production and Utilization of Biogas in Rural Areas of Industrialized and Developing Countries", 1985.

${ }^{206}$ J. Hohfeld and L. Sasse, "Production and Utilization of Biogas in Rural Areas of Industrialized and Developing Countries", 1985.

${ }^{207}$ F owler S., "A System Approach to Biogas Technology", accessed on the $24^{\text {th }}$ of May 2007.

${ }^{208}$ Shannon R., "Biogas", September 27 to October 7, 1996.

209 "Energy for Rural Development, Renewable Resources and Alterative Technologies for Developing Countries", 1981.

210 "Methane Generation from Human, Animal and Agricultural Wastes", 1977.

${ }^{211}$ J. Hohfeld and L. Sasse, "Production and Utilization of Biogas in Rural Areas of Industrialized and Developing Countries", 1985.

${ }^{212}$ J. Hohfeld and L. Sasse, "Production and Utilization of Biogas in Rural Areas of Industrialized and Developing Countries", 1985.

${ }^{213}$ David Fulford, "Running a Biogas Programme", 1988.

214 "Dissemination of Biogas Plants In Rural Areas of Kenya", 1987.

${ }^{215}$ David Fulford, "Running a Biogas Programme", 1988.

${ }^{216}$ David Fulford, "Running a Biogas Programme", 1988.

${ }^{217}$ Kuria K. J., "Extending the Existing Solutions for Domestic Production of Biogas for a Single Homestead to Institutional Provisions", 2004.

218 "Dissemination of Biogas Plants In Rural Areas of Kenya", 1987.

${ }^{218}$ David Fulford, "Running a Biogas Programme", 1988.

219 "Methane Generation from Human, Animal and Agricultural Wastes", 1977.

${ }^{220}$ David Fulford, "Running a Biogas Programme", 1988.

${ }^{221}$ David Fulford, "Running a Biogas Programme", 1988.

222 "Methane Generation from Human, Animal and Agricultural Wastes", 1977.

${ }^{223}$ J. Hohfeld and L. Sasse, "Production and Utilization of Biogas in Rural Areas of Industrialized and Developing Countries", 1985.

${ }^{224}$ J. Hohfeld and L. Sasse, "Production and Utilization of Biogas in Rural Areas of Industrialized and 
Developing Countries", 1985.

225 "Methane Generation from Human, Animal and Agricultural Wastes", 1977.

${ }^{226}$ J. Hohfeld and L. Sasse, "Production and Utilization of Biogas in Rural Areas of Industrialized and Developing Countries", 1985.

227 "Methane Generation from Human, Animal and Agricultural Wastes", 1977.

${ }^{228}$ J. Hohfeld and L. Sasse, "Production and Utilization of Biogas in Rural Areas of Industrialized and Developing Countries", 1985.

${ }^{229}$ J. Hohfeld and L. Sasse, "Production and Utilization of Biogas in Rural Areas of Industrialized and Developing Countries", 1985.

${ }^{230}$ David Fulford, "Running a Biogas Programme", 1988.

${ }^{231}$ David Fulford, "Running a Biogas Programme", 1988.

${ }^{232}$ Kuria K. J., "Extending the Existing Solutions for Domestic Production of Biogas for a Single Homestead to Institutional Provisions", 2004.

${ }^{233}$ Kuria K. J., "Extending the Existing Solutions for Domestic Production of Biogas for a Single Homestead to Institutional Provisions", 2004.

${ }^{234}$ David Fulford, "Running a Biogas Programme”, 1988.

${ }^{235}$ J. Hohfeld and L. Sasse, "Production and Utilization of Biogas in Rural Areas of Industrialized and Developing Countries", 1985.

${ }^{236}$ Shannon R., "Biogas", September 27 to October 7, 1996.

237 "Bioconversion of organic residues for rutal communities", accessed on the $24^{\text {th }}$ of May 2007.

${ }^{238}$ David Fulford, "Running a Biogas Programme", 1988.

${ }^{239}$ El-Halwagi, M. M., "Biogas Technology Transfer and Diffusion”, Elsevier applied $\quad$ Science publishers, London, UK, 1984.

${ }^{240}$ Eggling G., Guldager R., Hilliges H., Sasse G., Tietjan L. and Werner C., "Biogas Manual for Realization of Biogas Programmes", BORDA, Bremen, West Germany, 1979.

${ }^{241}$ Maina Maringa, Notes on Biogas generation and sizing of Biogas units, 1996.

${ }^{242}$ Kuria K. J., "Extending the Existing Solutions for Domestic Production of Biogas for a Single Homestead to Institutional Provisions", 2004.

${ }^{243}$ Kuria K. J., "Extending the Existing Solutions for Domestic Production of Biogas for a Single Homestead to Institutional Provisions", 2004.

${ }^{244}$ Kuria K. J., "Extending the Existing Solutions for Domestic Production of Biogas for a Single Homestead to Institutional Provisions", 2004. 